\title{
A ASCENSÃO CHINESA, AS TRANSFORMAÇÕES DA ECONOMIA-MUNDO CAPITALISTA E OS IMPACTOS SOBRE OS PADRÕES DE COMÉRCIO NA AMÉRICA LATINA
}

\author{
Alexandre de Freitas Barbosa'
}

Este artigo realiza uma discussão em torno do conceito de economia-mundo capitalista, procurando mostrar o seu potencial analítico para explicar o processo de transformação no funcionamento da economia global antes e depois da crise de 2008. Com base nesse aparato teórico são apresentados os diversos padrões de comércio estabelecidos entre a China e algumas regiões centrais e periféricas entre os anos 2000 e 2016, com o objetivo de apontar especialmente como isso impacta os países latino-americanos. A ascensão chinesa e os vários modelos de inserção externa desses países têm provocado um processo de desintegração e fragmentação da América Latina, sobretudo em termos econômicos, trazendo novos dilemas para o desenvolvimento da região.

Palavras-chave: capitalismo; globalização; ascensão chinesa; desenvolvimento; integração regional.

\section{THE RISE OF CHINA, CHANGES IN THE CAPITALIST WORLD-ECONOMY AND IMPACTS TO TRADE PATTERNS IN LATIN AMERICA}

This article seeks to developed the concept of capitalist world-economy in order to demonstrate its analytical potential for understanding the transformation of the "global economy" before and after the 2008 crisis. This theoretical approach is key for understanding the trade patterns developed between China and some central and peripheral regions in the period 2000-2016. Its main purpose is to stress the unfolding of different trade patterns in the countries of Latin America. The rise of China and the models of international integration of these countries have led to a process of disintegration and fragmentation of Latin America at least in economic terms, thus bringing about new dilemmas for the development of the region.

Keywords: capitalism; globalization; rise of China; development; regional integration.

\section{EL ASCENSO CHINO, LAS TRANSFORMACIONES DE LA ECONOMÍA-MUNDO CAPITALISTA Y LOS IMPACTOS SOBRE LOS PATRONES DE COMERCIO EN AMÉRICA LATINA}

El artículo desarrolla una discusión conceptual sobre la economía-mundo capitalista con la intención de verificar su potencial analitico para explicar la transformación de la "economía global" antes y después de la crisis de 2008. Con base en esa reflexión teorica, se presentan los patrones de comercio conformados entre China y algunas regiones centrales y perifericas del mundo entre los años 2000 y 2016. El objectivo es presentar los diversos patrones de comercio emergentes en los países de América Latina. 0 sea, el ascenso chino y los modelos de inserción externa de esos

1. Professor de história econômica e economia brasileira e internacional do Instituto de Estudos Brasileiros da Universidade de São Paulo (IEB/USP); e bolsista produtividade do Conselho Nacional de Desenvolvimento Científico e Tecnológico (CNPq) (categoria 2).E-mail: <afbarbosa@usp.br>. Orcid: <https://orcid.org/0000-0002-0493-7488>. 
paises han llevado a un proceso de desintegración e fragmentación de América Latina al menos em términos ecconómicos, lo que impone nuevos dilemas para el desarrollo de la región.

Palabras clave: capitalismo; globalización; ascenso chino; desarrollo; integración regional.

JEL: F630, F150, B520.

DOl: http://dx.doi.org/10.38116/rtm24art5

Data de envio do artigo: 10/8/2020. Data de aceite: 25/9/2020.

\section{INTRODUÇÃO}

Este artigo parte do pressuposto de que a utilização do "global" como mero adjetivo seja na "economia global" dos economistas neoclássicos, seja no "capitalismo global" dos economistas marxistas - acaba por ofuscar a compreensão das mudanças estruturais verificadas na economia e na política do mundo contemporâneo. $\mathrm{O}$ adjetivo global, tal como utilizado, sugere a inexistência de diferenças expressivas entre os vários centros e as várias periferias da economia-mundo capitalista - ou que essas diferenças e as interaçōes e contradições dela advindas não afetam a dinâmica do sistema. Desse modo, perdem-se de vista os novos processos de reorganização espacial e hierárquica ocorridos desde o último quarto do século XX.

Com este trabalho, visamos fornecer conceitos e categorias operacionais que possam dar conta da realidade objetiva da "economia-mundo capitalista", tal como (des)(re)organizada de maneira incessante no contexto histórico da ascensão chinesa. A seção 2 trata desse esforço de adaptação/atualização dos conceitos à essa nova realidade.

A seção 3 procura fornecer os contornos gerais da nova estrutura de funcionamento da economia-mundo capitalista pós-anos 1980. Segundo nosso prisma de análise, a crise financeira de 2008 - que atingiu inicialmente as regióes centrais do Atlântico Norte para depois ser empurrada para a periferia e semiperiferia do sistema - aparece como sintoma e manifestação de transformaçóes mais amplas.

$\mathrm{Na}$ seção 4 são apresentados, de maneira sintética, os padróes de comércio vigentes entre a China e regióes do mundo, centrais e periféricas, com dados para o período 2000-2015. O quadro apresentado não parece ter se alterado de forma substantiva até 2019, e tudo índica que ocorrerão mudanças importantes relacionadas às tensões entre Estados Unidos e China, principalmente no contexto pós-pandemia.

O foco recai sobre a América Latina na seção 5, em que se procura apontar como a ascensão chinesa levou, na prática, à conformação de diversos padróes de comércio na regiâo. Essa é apenas umas das maneiras de ilustrar o processo de desintegração e fragmentação da América Latina, ao menos em termos econômicos.

No nosso entender, sem a compreensão dessas transformações, qualquer debate sobre integração regional ou sobre desenvolvimento já surge ultrapassado. 
A pergunta de fundo parece ser: como é possível debater neste novo contexto a integração regional e o desenvolvimento na América Latina? Se os efeitos da pandemia se fizeram sentir de maneira mais grave na região, qualquer raciocínio prospectivo deve levar em consideraçáo os vários padróes de inserção externa vigentes antes de 2020 .

\section{OS CONCEITOS IMPORTAM: O PORQUÊ DE ECONOMIA-MUNDO CAPITALISTA}

Todo cientista social precisa de conceitos para se comunicar. Alguns conceitos, entretanto, de tão utilizados, perdem com o tempo a sua capacidade explicativa (Koselleck, 2011). Às vezes, chegam a aparecer sob o mesmo figurino, mas com significados bastante diversos, senão opostos. $\mathrm{O}$ processo avança mais rápido do que o significante que pretende - em tese, ao menos - captar o seu sentido.

O conceito de globalização, apesar de servir de referência para líderes políticos, militantes sociais e para boa parte da comunidade acadêmica, não dá conta da complexidade do quadro econômico e geopolítico do período pós-1980.

Vale ressaltar que o chamado processo de globalização - caracterizado pela possibilidade de desterritorialização da produção, mas não apenas - acabou sendo ofuscado pelo "discurso da globalização", segundo o qual todas as economias deveriam se curvar aos ditames do mercado, em busca de um ideal abstrato de competitividade (Hobsbawm, 2000).

De fato, durante os vinte anos que separam a queda do Muro de Berlim da quebra do banco de investimentos Lehman Brothers, em 2008, o mundo foi acometido pelo que Stiglitz (2010) chama de ascensão e queda do fundamentalismo de mercado, o qual coincidiu com o curto período de "triunfalismo norte-americano". Agora que o "discurso da globalização" começa a ruir, talvez seja o momento de revisitar o processo por meio de novos conceitos, mais aderentes ao real, e menos apologéticos.

O conceito transformou-se em ideologia de um tempo histórico, quando então se predicou que o mundo se havia tornado plano, segundo a pretensão de Friedman (2006). Um mundo feito de múltiplas interconexōes horizontais e desprovido de hierarquias.

Recheada de exemplos do mundo empresarial, a obra de Friedman - que também obteve alcance global - professava uma "globalização 3.0", ancorada nos indivíduos capazes de competir globalmente, desde que fossem criativos e aproveitassem as oportunidades fornecidas pelo "mundo plano". Segundo o autor, "o trabalho é feito onde ele pode sê-lo de maneira mais efetiva e eficiente" [já que] "o trabalho e o capital foram libertados" em benefício da competitividade (Friedman, 2006).

Os exemplos prediletos do autor são as novas Shenzhens e Bangalores, além das "velhas" Londres e Nova Yorks, que passam a concentrar as atividades intensivas 
em conhecimento. Enfim, um misto de autoajuda e de histórias de sucesso que não capturam a reorganização hierárquica e desigual das regiōes redesenhadas de acordo com a nova estrutura da economia-mundo capitalista.

Seguindo uma abordagem diversa, Dicken (1998) aponta para a existência de "forças globalizantes em ação", mas que não são suficientes para engendrar uma "economia mundial plenamente globalizada". O autor diferencia os processos de internacionalização - que envolvem a simples extensão de atividades econômicas para além das fronteiras nacionais - da "globalização", que vai além, pois "integra funcionalmente estas atividades dispersas". No seu entender, a crescente interconectividade acelera a complexidade geográfica - pois as escalas local, nacional e supranacional se articulam de maneira desigual - e aguça a volatilidade por meio da constante mudança dos fluxos econômicos e de informaçóes, gerando assim novas hierarquias, que, por sua vez, afetam a distribuição de poder, gerando novas hierarquias, que afetam por sua vez a distribuiç, de mBrothers, o mundo teria sido acometido pelo que Stiglitz.

Quebrando o mito da corporação transnacional deslocalizada ou global, ele reforça a complexidade do processo ao apontar o nexo triangular que envolve relaçóes empresa-empresa, Estado-Estado e empresa-Estado, com distintas configuraçóes a depender do setor econômico em questão e do poder de barganha estatal das várias naçôes (Dicken, 1998).

Partindo da hipótese de que "o espaço organiza o tempo na sociedade em rede", Castells (2000) contrapóe uma nova lógica espacial, o "espaço de fluxos", à lógica historicamente enraizada na experiência comum, o "espaço dos lugares". O que desponta no seu horizonte analítico é o avanço irreversível do espaço dos fluxos. Nesse contexto, hierarquias socioespaciais reais e simbólicas se interpenetram, permitindo a emergência de um espaço relativamente segregado ao longo das linhas conectoras do espaço de fluxos.

Sassen (2003) se refere inclusive a uma nova "geografia econômica da centralidade", que atravessa as fronteiras nacionais e a antiga divisão entre o norte e o sul. Novas periferias surgem nos antigos centros e novos centros nas antigas periferias.

Portanto, para além das divisóes habituais entre mundo rural e mundo urbano, norte global e sul global, Oriente e Ocidente, "capacidades sistêmicas" ativadas por meio da combinação de inovaçóes técnicas, de mercado e de finanças, com apoio de alguns Estados nacionais - cuidam de fincar o sistema capitalista de maneira diferencial em vários locais. $\mathrm{O}$ que preside essa lógica é um conjunto de "novas lógicas de expulsão", em relação ao que não é conectado, mas também ao que é conectado de maneira brutal. A própria divisão entre países desenvolvidos e subdesenvolvidos parece perder sentido (Sassen, 2016). 
Nesse sentido, as categorias usuais que dariam conta de uma interpretação da realidade global contemporânea, mostram-se cada vez mais limitadas. De modo a realçar as forças sistêmicas que incidem sobre os vários espaços de forma quase subterrânea - pois a sua articulação global/local aparece enevoada -, a autora nos convida a um esforço de "desteorização" (Sassen, 2016).

No nosso entender, esse esforço, se permite desintoxicar o "discurso da globalização”, deve vir acompanhado de um exercício, sempre preliminar, de (re) teorização. Nosso desafio é recuperar algumas categorias de Fernand Braudel, Immanuel Wallerstein e Giovanni Arrighi - concebidas para o capitalismo histórico na sua manifestação recorrente e diferenciada entre os séculos XV e $\mathrm{XX}$ - para iluminar alguns processos e tendências verificados no período recente.

Comecemos com Fernand Braudel, que mobiliza o conceito de economia-mundo. Ao contrário da "economia mundial" que engloba tudo, a "economia-mundo" é um fragmento do universo, relativamente autônomo, que se basta a si próprio. Possui certa organicidade e coerência, funcionando como a camada superior da vida econômica, muitas vezes transcendendo o limite dos impérios (Braudel, 1996a). Por certo são vários os fragmentos acionados pelas várias fraçôes de capital - de maneira complementar e contraditória. Eles, porém, não integram tudo. Tampouco existem mais impérios. A "civilização capitalista" (Wallerstein, 1995) se expande fincando raízes pelo mundo reconquistado para o capital, e muitas vezes dissolvendo as tessituras econômicas, sociais e geográficas na medida em que a corrente passa.

Para Braudel (1996a), toda economia-mundo possui regras tendenciais: um limite geográfico, um centro onde já desponta desde cedo um "capitalismo" dominante no espaço hierarquizado, além de zonas secundárias razoavelmente desenvolvidas e enormes margens exteriores ou periféricas. O quadro é bem mais complexo, pois existe, no entender do historiador francês, um escalonamento - ou melhor, hierarquias - tanto nos centros como nas áreas periféricas, especialmente nos seus pontos de conexão com a economia-mundo.

Lembremos que essa análise de Braudel se refere ao período que compreende os séculos XV a XVIII. Contudo, se naquela época os centros hegemônicos se sucediam, agora eles atuam de maneira coordenada e conflituosa. A sua capacidade de irradiação é maior em escala (por conta da "terceirização global") e menor em escopo, pois as regiôes contíguas aos centros se ressentem do privilégio concedido à finança e às atividades de gestão das capacidades sistêmicas, especialmente nos centros antigos, porém remanescentes, Estados Unidos e Uniâo Europeia (UE).

Essa aposta metodológica nos parece ser a que mais se encaixa na necessidade de compreensão da diversidade da economia e da política contemporâneas, em que os vários espaços centrais e periféricos conseguem com maior ou menor autonomia- 
seguramente com menor autonomia do que no período 1850 a 1980 - se vincular ao mundo do capitalismo, gerando efeitos limitados sobre as suas economias de mercado internas. A China é a exceção que confirma a regra. Muito provavelmente, por sua capacidade de fundir os dois modelos - o capitalismo dos sistemas nacionais (1850 a 1950) e o capitalismo das firmas transnacionais (1950 a 1980) aplicado na periferia a partir de uma nova relação com o centro. ${ }^{2}$

Voltando a Braudel (1996b), o autor define o capitalismo como a "zona do contramercado", onde desponta o monopólio. No seu entender, o capitalismo, em vez de emergir da livre iniciativa, se aninha justamente onde se encontra a interseção entre o Estado e o mercado para alavancar a acumulação de capital. Ao fazê-lo, estende os seus tentáculos sobre a economia de mercado, responsável pelas ligaçôes mais constantes entre os agentes econômicos e por certo automatismo ligando oferta, procura e preços. Escavando um pouco mais, podemos encontrar, ainda segundo Braudel (1996b), um enorme andar térreo da vida material, a zona do inframercado (ou autoconsumo), "onde o mercado lança suas raízes, mas sem o prender integralmente".

Depois dos anos 1980, com a reconfiguração geográfica do capitalismo que faz interagir mudança tecnológica, expansão financeira e ocupaçẫo de novos mercados -, são estabelecidas novas ligaçóes verticais entre as várias economias locais e nacionais, a partir dos territórios centrais da economia-mundo capitalista. São assim restringidos os espaços nacionais de acumulação que davam guarida a uma classe média e uma classe trabalhadora assalariada, inclusive em alguns países da semiperiferia industrializada. Não apenas, as zonas de autoconsumo são lançadas ao mercado, gerando um excedente de força de trabalho impossível de ser incorporada/explorada pelas redes de baixa densidade que vinculam a produção capitalista desterritorializada na extensa periferia das zonas de comando.

Poderíamos até sugerir que o capital ao residir novamente, ainda que não de maneira exclusiva ou prioritária, na esfera financeira ao final do século XX, Braudel estaria "dando o troco" às interpretaçóes marxistas contemporâneas que enxergam um "regime de acumulação financeirizado" (Chesnais, 2005). Ora, a aposta nesse "novo" regime de acumulação global perde de vista a crescente complexidade da economia-mundo capitalista.

No seu esquema metodológico, acompanhado de uma interpretação histórica peculiar, Braudel (1985) ressalta como a preponderância econômica inglesa, no contexto da Revolução Industrial, traz no seu bojo a ruptura de um processo multissecular, engendrando agora uma "verdadeira economia mundial". É quando o capitalismo sai (jamais inteiramente) do espaço onde se sente em

2. Esses dois modelos históricos foram sintetizados por Furtado (2000) em sua última obra teórica, sem fazer menção à China. 
casa - a esfera da circulação comercial e financeira - e adentra em casa alheia (não para sempre), o espaço da produção. Rompe-se agora a primazia das economias sob comando urbano e suas várias economias-mundo circundantes, incapazes, apesar de sua desenvoltura, de ampliar o seu alcance para assimilar o conjunto do universo.

Braudel, entretanto, não chega a lançar o conceito de economia-mundo capitalista. Quem o faz, seguindo o seu rastro, é Immanuel Wallerstein. Por meio desse conceito, o autor abarca a expansão da economia-mundo europeia pelo globo no século XIX, irradiando-se para o outro lado do Atlântico Norte, subordinando os recém-independentes países latino-americanos, já sem a intermediação ibérica, e incorporando parcelas expressivas dos continentes asiático e africano à periferia do novo sistema, agora que os "impérios-mundo" foram esquartejados e os "minissistemas" perderam sua autonomia. Criam-se, entấo, novas posiçóes estruturais - centro, semiperiferia e periferia - na nova escala ampliada dessa economia-mundo capitalista, as quais se apresentam com estruturas de classes correspondentes ao seu papel no sistema mais amplo. A complexidade da estrutura de poder, por sua vez, impede a emergência de um novo império (Wallerstein, 1979).

A principal limitação do esquema analítico do sociólogo estadunidense está em encarar o mecanismo do desenvolvimento econômico, no âmbito do capitalismo, como meramente quantitativo, oriundo da ampliaçáo das relaçôes de troca. Ele mesmo pontifica: o capitalismo é um modo de produção global, ou seja, "de produção para obtenção de lucro no mercado", que não exige necessariamente a mercantilização da força de trabalho, saltando, dessa forma, para fora do escopo analítico de Marx (Wallerstein, 1979).

Como ficamos então? A solução para esse dilema nos é fornecida parcialmente por Giovani Arrighi, a partir de um diálogo entre as contribuiçôes de Braudel e Marx. A fusão dos dois enfoques leva aos "ciclos sistêmicos de acumulação" possuindo duração de cerca de um século e funcionando a partir da alternância de formas de organização de produção e de centros hegemônicos (leia-se ciclo genovês, holandês, britânico e norte-americano) - que configuram "padrōes diversos de repetição e evolução do capitalismo histórico como sistema mundial", articulados, por sua vez, às disputas de poder interestatal. Períodos de mudanças contínuas (expansão material) se fazem suceder por mudanças descontínuas (expansão financeira), quando então se presencia a rearticulação hegemônica sob a liderança de novos agentes governamentais e empresariais (Arrighi, 1996).

Concomitantemente, em cada ciclo se reconstrói um regime de acumulação capitalista em escala mundial, permitindo escoar a economia-mundo capitalista nos seus vários momentos, enquanto redefine hierarquias e configuraçôes espaciais. 
Se esse quadro serve de horizonte analítico para compreender a crise dos Estados Unidos como potência hegemônica, nada indica que o padrão anterior será reproduzido, ou seja, que veremos a emergência de novas potências capitalistas de ordem superior, algo que o próprio Arrighi (1996) parece duvidar, mesmo na obra dedicada à compreensão da reviravolta ocasionada pela ascensão chinesa (Arrighi, 2007).

Como tentaremos desenvolver adiante, o desenvolvimento do poder capitalista tanto teria atingido tal alcance e escala em termos geográficos, segundo a interpretaçáo arrighiana, que a sua gestáo parece depender de um novo consenso geopolítico. Trata-se de um consenso diferente do passado, mais próximo de uma ordem multipolar, em que os vários centros - com participação agora mais relevante de suas semiperiferias - passam a se responsabilizar pela gestão coordenada do sistema-mundo, ainda que permeada por conflitos de toda ordem.

Nesse sentido, a China passa a figurar cada vez mais como um novo centro dinâmico da economia-mundo capitalista, cuja configuração passa a depender da forma como são revolvidas ou não as tensóes e disputas, por meio de consensos provisórios com os outros dois centros, Estados Unidos e UE, que repercutem sobre as novas periferias e semiperiferias.

Apenas a título de ilustração, segundo marco teórico aqui utilizado, a política recente de Donald Trump de imposição de tarifas e barreiras ao comércio com a China, assim como a restrição aos investimentos externos diretos desse país nos Estados Unidos, não devem ser vistas como políticas "nacionalistas", "populistas" ou "desglobalizantes". Trata-se de uma resposta, entre as tantas possíveis, a uma situação de reorganização do capitalismo, num contexto de excedente de capital viabilizado por meio dos "ajustes espaciais" (Harvey, 2006).

Podemos entender a ascensão chinesa como a emergência de uma "nova coerência estruturada" no território, por meio da coalizão de interesses sedimentada pelo Estado - sob controle do Partido Comunista Chinês -, com apoio inclusive das transnacionais dos Estados Unidos e da UE, permitindo um novo ciclo expansivo ao capitalismo, não "global", mas sedimentado nas novas interaçóes que ultrapassam os territórios nacionais. Por meio do ajuste espacial, entretanto, os processos globais de lutas de classe, segundo Harvey (2006), se dissolvem em conflitos interterritoriais. Para complicar o cenário, as várias frações de capital das coerências estruturadas antigas se encontram desigualmente vinculadas ao território de origem. Veja-se, por exemplo, a finança desregulada com sede nos Estados Unidos e na UE, ou as filiais das empresas transnacionais com sede nessas regiôes, que ativam, por meio de suas redes de produçâo, parcelas expressivas do território global que não necessariamente atuam no intuito de defender as antigas coerências estruturadas. 
Finalmente, vale lembrar que os autores citados anteriormente tendem a ver as periferias do capitalismo a partir de uma abordagem totalizante, às vezes perdendo de vista as suas peculiaridades. Os teóricos latino-americanos - da Comissão Econômica para a América Latina e o Caribe (CEPAL) e da "teoria da dependência" - fizeram o movimento inverso, na tentativa de capturar a desigualdade congênita do desenvolvimento global a partir das relaçóes assimétricas entre o capitalismo central e o periférico, sempre cambiantes, além de geradoras de diversas possibilidades de desenvolvimento "internas" (Prebisch, 1981).

Nesse sentido, Furtado (1974), por exemplo, articula dinamicamente os conceitos de subdesenvolvimento e dependência, a partir da experiência latino-americana. Por subdesenvolvimento, ele entende "a forma de vinculação de estruturas socioeconômicas surgidas nas áreas onde o sistema de divisão internacional do trabalho permitiu que o produto líquido crescesse mediante simples rearranjos no uso da força de trabalho disponível”. Mais adiante, o autor complexifica o seu aparato analítico original, de modo a compreender o "subdesenvolvimento industrializado" da experiência brasileira - o qual gera descontinuidades no aparato produtivo e uma heterogeneidade tecnológica, mas sem transformar inteiramente as estruturas econômicas - permitindo, assim, a entronização da heterogeneidade social. O Brasil, segundo esse enfoque, seria um caso limite de desenvolvimento dependente (Evans, 1979).

Portanto, o desenvolvimento da economia-mundo capitalista apresenta-se de maneira diferenciada no tempo e no espaço, gerando constelaçóes de forças sociais heterogêneas, especialmente na periferia, que podem atuar no sentido de aprofundar ou atenuar a dependência. Nada indica, entretanto, que a reiteração do subdesenvolvimento e da dependência seja "uma necessidade, uma consequência inelutável do modo capitalista de produção" (Furtado, 2000). O processo deve ser analisado a partir da sua constante e renovada manifestação histórica.

Daí porque as obras de Prebisch e de Furtado, assim como as mencionadas anteriormente nesta seçáo, servem apenas como ponto de partida. Esses conceitos precisam ser retrabalhados se quisermos capturar as mudanças em curso no período pós-1980. Cabem então as perguntas: existem vários capitalismos centrais e periféricos? Ou não seria a economia-mundo capitalista que é refundada a partir dos seus centros hegemônicos antigos, eles mesmos forçados à adaptação em face da emergência do novo centro econômico chinês? Que espaço essa nova dinâmica triangular verificada no topo do capitalismo abre para as economias periféricas? Existe nelas um capitalismo peculiar ou apenas mecanismos de integração subordinada, com maior ou menor potencial de ativar conexóes estruturadas no seio das naçóes e regióes? As novas formas de enrijecimento da dependência não acarretariam apenas a manifestação de formas diferenciadas de 
subdesenvolvimento, agora inclusive se expandindo rumo a algumas áreas das regiōes centrais?

A partir de todo o esforço teórico apresentado, e das perguntas que ele suscita, procuramos destrinchar os contornos básicos da nova economia-mundo capitalista no contexto da ascensão chinesa, assim como da divisão internacional do trabalho correspondente, ainda em processo de consolidação. Se a economia-mundo capitalista vive de territórios privilegiados de acumulaçáo que se entrosam e se atritam, é por meio dos seus embates e da sua projeção sobre o resto do mundo que se podem perceber os constrangimentos e oportunidades para as regióes periféricas e semiperiféricas, diferentes dos presenciados em outros momentos históricos. Como decorrência, as estratégias de desenvolvimento não podem ser as mesmas do passado, pois dependem, em última instância, da posição estrutural, mas não rígida, que os vários países da América Latina ocupam nesse quadro mais amplo.

\section{A ASCENSÃO CHINESA E A RECONFIGURAÇÃO DA ECONOMIA-MUNDO CAPITALISTA}

A ascensão chinesa vem contribuindo para alterar, sobretudo desde os anos 1990, a estrutura de funcionamento da economia-mundo capitalista. Boa parte das análises concentra-se nos efeitos da China sobre o crescimento da "economia global", no seu impacto sobre o preço das commodities ou ainda sobre a oferta de capital para a periferia do sistema, como se esse algo "novo" se somasse ao que vinha antes. O máximo que se "admite" é que a China teria aderido à globalização, fazendo-a funcionar a seu favor.

Por mais importantes que sejam esses estudos - geralmente elaborados para investidores ou por economistas do mercado provenientes dos países ocidentais -, eles tendem a perder de vista que a própria economia mundo-capitalista passa por uma reconfiguração decisiva, visível já nos anos 1990 e acelerada durante os anos 2000 .

A crise financeira de 2008, por sua vez, levou a um acirramento da disputa entre os três centros hegemônicos - Estados Unidos, UE e China - por novas posiçóes econômicas e geopolíticas. Segundo a nossa perspectiva, a desvalorização do euro e do dólar no pós-crise e a lenta recuperaçáo das economias do Atlântico Norte, agora em busca de novos mercados, tornaram patentes as contradições entre os três centros da economia-mundo capitalista, ao contrário do período anterior onde havia certa complementaridade. Hoje predomina a corrida rumo aos setores de vanguarda tecnológica, até então resguardados a Estados Unidos e União Europeia e, em alguma medida, a Japão e Coreia do Sul.

A ascensão chinesa dá-se em virtude de seu entrosamento com a nova economia-mundo capitalista, avançando rumo a setores de maior valor agregado - 
que produzem para o seu mercado interno e para o externo -, acarretando assim uma diversificação do centro dinâmico em escala global. Esse processo consolidou-se especialmente nos anos 2000, já que durante os anos 1990 a presença chinesa se fazia sentir enquanto exportadora de produtos processados de baixa e média tecnologia, aproveitando-se dos grandes fluxos de investimentos estrangeiros diretos (IEDs) que desembarcaram no seu território. Desse modo, os elos mais intensivos em capital ainda estavam sob controle das empresas transnacionais dos antigos centros dinâmicos.

Com a ascensão chinesa, a economia mundo-capitalista experimentou uma extroversão dos centros dinâmicos de acumulação capitalista para além do Atlântico Norte. A costa leste chinesa, apesar de sua posição ainda subordinada, passou a compor nos anos 1990 - junto com as economias dominantes, europeia e norte-americana - os espaços centrais de acumulação de capital, poder e tecnologia. Não se pretende discutir aqui se a China é uma economia capitalista ou uma forma de socialismo de mercado. Para os fins deste artigo é suficiente a constatação de que um segmento cada vez mais amplo da economia chinesa possui alta rentabilidade e competitividade, capaz de redefinir o modus operandi da economia-mundo capitalista.

Algumas economias como Brasil, Índia, Rússia, África do Sul e outras do Sudeste Asiático - caracterizadas aqui como economias semiperiféricas - ${ }^{3}$ ascenderam, em alguns setores, na divisão internacional de trabalho - algumas mais, outras menos favorecidas pela ascensão chinesa -, em virtude da sua competitividade externa em algumas atividades e da dimensão dos seus mercados internos, acionando dessa forma mecanismos endógenos de acumulação de capital. Diferentemente da China, porém, não conseguiram promover uma reconversão produtiva no sentido dos setores intensivos em capital e tecnologia. Nesse contexto, a dependência é, na melhor das hipóteses, atenuada, ainda que não deixe de se afirmar como traço estrutural.

A tradicional periferia localizada nos países desindustrializados ou jamais industrializados, na América Latina, no sul da Ásia e em boa parte da África, voltou a apresentar, nos anos 2000, elevados níveis de crescimento, em grande medida puxados pela demanda de commodities chinesa. Esses países ressentem-se, contudo, da estreiteza dos seus mercados internos. A dependência se cristaliza, pois necessitam de mercados para seus poucos produtos e de fluxos de capitais provenientes não apenas das três sedes dinâmicas da economia mundo-capitalista. Além da típica clivagem Norte-Sul, percebe-se também uma divisão Sul-Sul, estabelecendo, assim, um cenário de múltiplas dependências.

3. Sobre esse conceito, ver Arrighi (1997). 
Em síntese, por um lado, configura-se um centro dinâmico expandido com disputas crescentes nos setores de fronteira tecnológica e na diferenciação dos padrōes de consumo, enquanto são engendradas novas periferias internas, engolfadas na crise resultante do processo de financeirização do Atlântico Norte, como no caso do sul da Europa e de certas regióes dos Estados Unidos, abrindo espaço para um novo quadro de dependências relativas (vide Grécia em relação à Alemanha, ou Detroit em relação ao Vale do Silício). Por outro lado, a China continua tendo que lidar com a polarização desenvolvimento/subdesenvolvimento ao longo do seu vasto território. O desenvolvimento do Leste, que trouxe um avanço espetacular das forças produtivas, não levou a uma redução das disparidades sociais e regionais; antes pelo contrário.

$\mathrm{O}$ novo entrosamento entre os vários centros, semiperiferias e periferias da economia-mundo capitalista não tem os seus contornos ainda plenamente definidos no pós-crise de 2008. A desaceleração da economia chinesa - já verificada antes da pandemia - pode detonar inclusive uma nova forma de inserção dos setores dinâmicos desse país na economia-mundo capitalista. A tendência de exportaçóes de capitais e de internacionalizaçâo produtiva chinesa insere-se nesse quadro mais amplo.

Trata-se, portanto, de reduzir a dependência das exportaçóes de produtos industriais chineses, especialmente para os demais países do centro dinâmico, as quais seriam relocalizadas em vários pontos da economia-mundo capitalista. O excesso de capacidade no mercado interno chinês em vários setores industriais e de infraestrutura poderia ser canalizado para outras partes do mundo por meio da criação de estruturas institucionais de suporte a investimento nos países da periferia e da semiperiferia com apoio inclusive das entidades financeiras chinesas.

Paralelamente, o salto rumo aos setores de fronteira tecnológica das empresas chinesas, atuando no seu mercado interno ou a partir de aquisiçóes de empresas dos países do núcleo dinâmico, reduziria a dependência atual de importações intensivas em tecnologia de Japão, Coreia do Sul, Alemanha e Estados Unidos. É nesse contexto que devem ser vistas as ações do governo Trump de dificultar o ingresso do investimento externo direto chinês nos Estados Unidos, algo que também acontece na UE, especialmente na Alemanha.

Apesar das recorrentes afirmaçóes que colocam a China como a "fábrica global", é importante ressaltar que apenas no final dos anos 2000 o país asiático superou os Estados Unidos como maior parque industrial do planeta, com uma participaçáo de cerca de $20 \%$ do total mundial, o que pode ser comparado aos $25 \%$ obtidos pelo Reino Unido em 1870, mas não com os quase 45\% dos Estados Unidos no início dos anos 1950 (Gao, 2012). No caso britânico de meados do século XIX, o destaque estava na participação do país nas exportaçóes industriais, enquanto 
nos Estados Unidos, um século depois, era o mercado interno que contribuía para a sua robustez industrial, não obstante a importância das exportaçôes. O caso chinês consegue conciliar envergadura do mercado interno com alta participação internacional, principalmente em bens industrializados, mas isso não significa que apareça como único centro privilegiado de acumulação. A sua expansão se dá num contexto de múltiplos centros industriais, tecnológicos e financeiros.

De acordo com os dados da United Nations Industrial Development Organization (UNIDO), ${ }^{4}$ 60\% do valor adicionado industrial global provêm desses três territórios centrais para a acumulação de capital - China, Estados Unidos e UE -, indicando mais uma vez a crescente multipolaridade que caracteriza a economia-mundo capitalista contemporânea.

A ascensão chinesa significa, portanto, mais e menos do que uma "desindustrialização" das demais regiôes do norte e do sul do planeta. A capacidade da economia chinesa de internalizar as cadeias produtivas - ou de regionalizá-las a partir do Sudeste Asiático - póe uma pá de cal nos anseios de uma "industrialização integral” nas demais regióes econômicas (Castro, 2008). Isso já havia se tornado praticamente irrealizável a partir dos anos 1990, com as políticas de abertura econômica, em vários países da periferia e da semiperiferia, e da reorganização dos fluxos por parte das empresas transnacionais. O contexto pós-pandemia, por mais que fortaleça a tendência à reorganização das cadeias produtivas em novas bases territoriais, não deve trazer uma total reversão desse quadro.

No quesito investimentos, desde o início da década de 1990, a China caracterizou-se como um dos principais países receptores de investimentos externos diretos. O dado mais surpreendente, entretanto, refere-se aos investimentos chineses no exterior, que saltam de valores muito baixos no final dos anos 1990, em torno de US\$ 1 bilhão, para US\$ 26 bilhóes em 2007, valor que duplica em 2008, ano da crise, e segue crescendo até atingir a marca de US\$ 100 bilhóes em 2013 (gráfico 1), perdendo apenas para os Estados Unidos, a UE e alguns paraísos fiscais, estes últimos inclusive contribuindo para subestimar a participação chinesa.

Os investimentos externos chineses são, em grande medida, realizados pelos grandes conglomerados estatais vinculados ao governo central, de onde provêm $75 \%$ dos IEDs globais chineses, o outro quarto ficando a cargo das estatais dos governos estaduais. A expansão desses investimentos no mercado internacional geralmente se dá sob a forma de fusôes e aquisiçốes (Shambaugh, 2013).

O gráfico 1 aponta para a mudança no modo de inserção da economia chinesa na economia-mundo capitalista, aproximando-se do ponto em que a sua

4. Disponível em: <https://www.unido.org/sites/default/files/files/2019-03/STA_Report_on_Quarterly_production_ 2014Q4.pdf>. 
exportação de capitais produtivos supera a importação. Para Scissors (2015), tal ponto teria sido alcançado no início de 2015.

Esse quadro tem a ver com a maior capacitação das empresas estatais chinesas, estimuladas a ocupar os mercados globais, inclusive dos outros dois territórios centrais de acumulação, não mais exclusivamente por meio das exportaçóes. Desse modo, as cadeias produtivas chinesas passam a se transnacionalizar para além do Sudeste Asiático, gerando novos e diversos fluxos de exportaçóes a partir do território chinês. Trata-se de uma continuidade com ruptura, que altera a estrutura de funcionamento da economia-mundo capitalista.

GRÁFICO 1

China: fluxos de IEDs no país e de investimentos externos no exterior (Em US\$ bilhões)

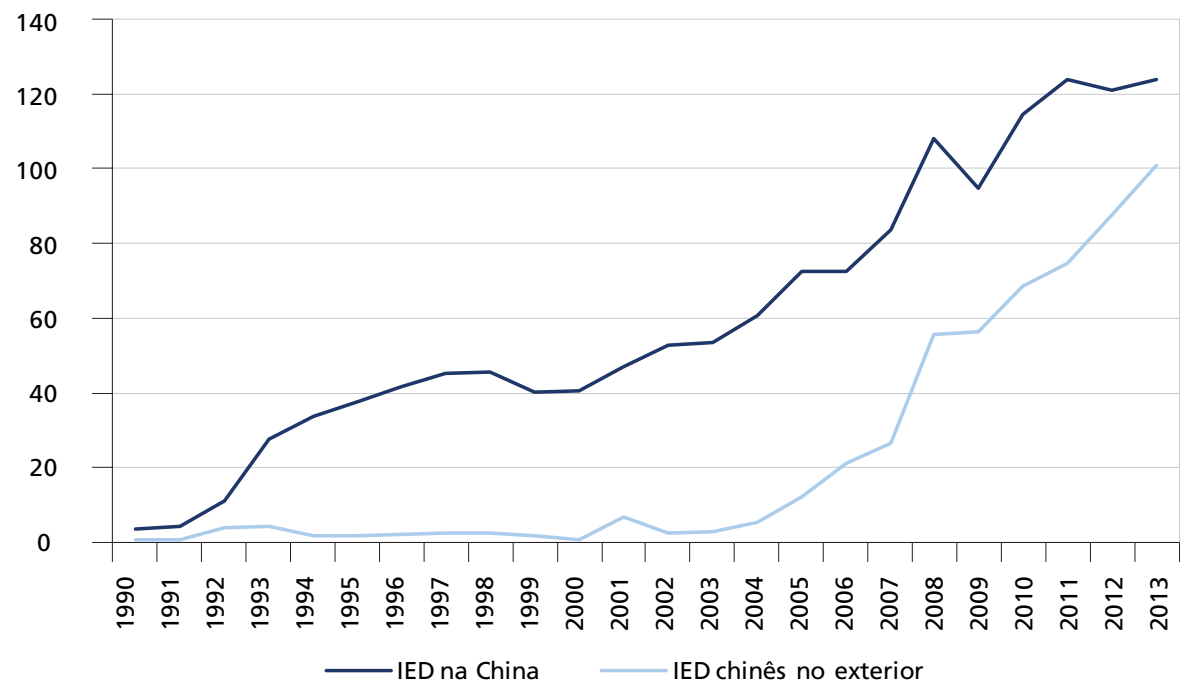

Fonte: Conferência das Nações Unidas sobre Comércio e Desenvolvimento (United Nations Conference on Trade and Development - UNCTAD), 2014.

Elaboração do autor.

Se a expansão chinesa passa a reorientar a dinâmica do comércio internacional, especialmente a partir do início dos anos 2000, os investimentos externos diretos e os empréstimos chineses assumem uma dimensão global apenas no final dos anos 2000. É importante ressaltar que essas três dimensóes aparecem interligadas.

Nesse sentido, a partir da crise de 2008, os fluxos de exportações chineses passam a estar mais diretamente relacionados à atuação das suas empresas no exterior - basicamente por meio de grandes conglomerados estatais - e aos fluxos de empréstimos fornecidos pelos seus policy banks, o China Development Bank (CDB) e o China Eximbank, ambos criados em 1994. 
O caso chinês revela como o controle da esfera financeira se faz estratégico para a disputa por mercado com os dois outros centros da economia mundial capitalista. Em vez do predomínio da alta finança globalizada financial capital (finança desregulada), temos o finance capital (Chesnais, 2016), ${ }^{5}$ ou seja, o capital financeiro estatal pilotando os esforços de acumulação de capital e de transformação produtiva no sentido da fronteira tecnológica. Essa é a marca distintiva da China em relação aos demais centros dinâmicos.

$\mathrm{O} \mathrm{CDB}$, o maior banco de desenvolvimento do mundo, depois de se voltar para a expansão de infraestrutura interna do país, passou a assumir papel de proa no processo de going global (tornar-se global), projetado pelo presidente Jiang Zemin ao longo da segunda metade dos anos 1990 (Shambaugh, 2013). Assim, em 2008, o banco já superava o Bank of China, como maior entidade financeira chinesa em volume de créditos internacionais.

Tal como o CDB, o China Exim capta recursos com a emissão de títulos no mercado interno, ainda que ambos tenham passado a lançar títulos no mercado internacional no período recente, já que são considerados pelas agências de rating como de risco soberano chinês (OECD, 2015). O China Eximbank concentra os seus créditos em exportaçấo, na modalidade de créditos ao vendedor (basicamente exportadores ou fornecedores de serviços chineses), ainda que, mais recentemente, a proporção de créditos ao comprador tenha crescido de maneira significativa.

Vale lembrar ainda que, em 2007, o volume de créditos a exportaçóes do Eximbank já era mais do que o dobro do verificado no Eximbank dos Estados Unidos e no Japan Bank for International Cooperation (JBIC), banco estatal japonês (Brautigam, 2009). O volume de empréstimos internacionais chegava a US\$ 96 bilhóes, representando 40\% do total da carteira do banco.

Dessa forma, a presença crescente da China nas economias periféricas e semiperiféricas náo pode ser imputada ao jogo das forças de mercado pura e simplesmente, ou apenas ao seu apetite por commodities. Antes e durante esse boom, o país, por meio de sua diplomacia econômica, conseguiu acionar mecanismos financeiros que possibilitaram a presença das grandes empresas estatais, não apenas no setor de combustíveis e minérios mas também fornecendo a infraestrutura para essas atividades, gerando assim um fluxo de exportaçóes de produtos mais intensivos em capital. Isso permitiu drenar para fora um excedente de capital chinês que passou a ficar cada vez mais visível depois da crise financeira dos países do Atlântico Norte, além de permitir que o país ocupasse um papel de destaque na geopolítica global.

5. Chesnais (2016) não aprofunda a diferença radical na China entre a finança desregulada e o capital financeiro estatal, diferença bem menos evidente nos Estados Unidos e na UE. 


\section{A CHINA E OS PADRÕES DE COMÉRCIO COM AS REGIÕES DA ECONOMIA-MUNDO CAPITALISTA}

Desdeasreformas de 1978, aChinaexperimentouváriospadróes dedesenvolvimento (Medeiros, 2013). A sua compreensão exige um acompanhamento das formas de inserção externa do país asiático, que foram paulatinamente se alterando junto com a configuração da economia-mundo capitalista.

Neste texto, focamos a dimensão comercial no período de 2000 em diante, envolvendo os anos anteriores e posteriores à crise de 2008. Não obstante, ressal tamos que essa dimensão apenas pode ser compreendida em sua complexidade por meio da interação com a dimensão dos investimentos externos diretos - pois o comércio intraempresas transnacionais assume relevância crescente - e junto com a dimensão financeira, que afeta as taxas de câmbio das principais economias.

Para dar conta da dimensão comercial, analisamos, em primeiro lugar, a presença da China como exportadora e importadora de bens industriais, em contraposição aos dois outros centros da economia-mundo capitalista, Estados Unidos e UE. Em seguida, procuramos compreender as relaçóes entre a China e as várias regióes do centro e da periferia, por meio dos saldos comerciais de bens industriais $(\mathrm{BK}+\mathrm{BC}+\mathrm{BI})^{6}$ e de matérias-primas.

Quando se retira o comércio intra-UE do total global, a participação chinesa nas exportações globais alcança 15\%, ficando apenas atrás do comércio extra-UE. Para o mesmo ano de 2013, as importaçóes chinesas representaram 13\% das importações globais, logo atrás de Estados Unidos e UE (tabela 1).

TABELA 1

China, Estados Unidos e UE: exportações totais em valor e percentual mundial (2013)

\begin{tabular}{|c|c|c|}
\hline & Valor (em US\$ bilhões) & Total (\%) \\
\hline \multicolumn{3}{|c|}{ Maiores exportadores } \\
\hline Extra-UE (27) ${ }^{1}$ & 2.307 & 15,3 \\
\hline China & 2.209 & 14,7 \\
\hline Estados Unidos & 1.580 & 10,5 \\
\hline \multicolumn{3}{|c|}{ Maiores importadores } \\
\hline Estados Unidos & 2.329 & 15,4 \\
\hline Extra-UE (27)' & 2.235 & 14,8 \\
\hline China & 1.950 & 12,9 \\
\hline
\end{tabular}

A expansão da China no comércio global deve ser, contudo, analisada, em termos setoriais. Isso porque o seu padrão de importaçáo mostra-se bifurcado

6. Soma de bens de capital (BK), bens de consumo (BC) e bens intermediários ( $\mathrm{BI}$ ). 
entre, de um lado, combustíveis, produtos minerais e commodities agrícolas; e, de outro, produtos industriais de alta tecnologia. Já no que refere às exportaçóes, mais de $90 \%$ são compostas de produtos industrializados.

No caso das exportaçóes de bens industriais, a China destaca-se como o maior exportador, superando UE e Estados Unidos entre 2000 e 2013. Nesse último ano, o país asiático já respondia por $23 \%$ das exportações mundiais de bens industriais, contra $32 \%$ quando somados os outros dois centros da economia-mundo capitalista (gráfico 2). A participação chinesa como importadora de bens industriais - geralmente de alto valor agregado - também se eleva, saltando de 4,8\% para 11,9\%, mas ficando ainda abaixo de Estados Unidos e UE (gráfico 3).

Observa-se ainda que a China possui uma participação que oscila entre $40 \%$ e 50\% das exportaçóes mundiais nos setores industriais de média e alta tecnologia como eletrônicos, equipamentos de telecomunicações e computadores, mas também nos setores mais tradicionais, como têxtil e vestuário.

\section{GRÁFICO 2}

China, Estados Unidos e UE: participação nas exportações mundiais de bens industriais (Em \%)

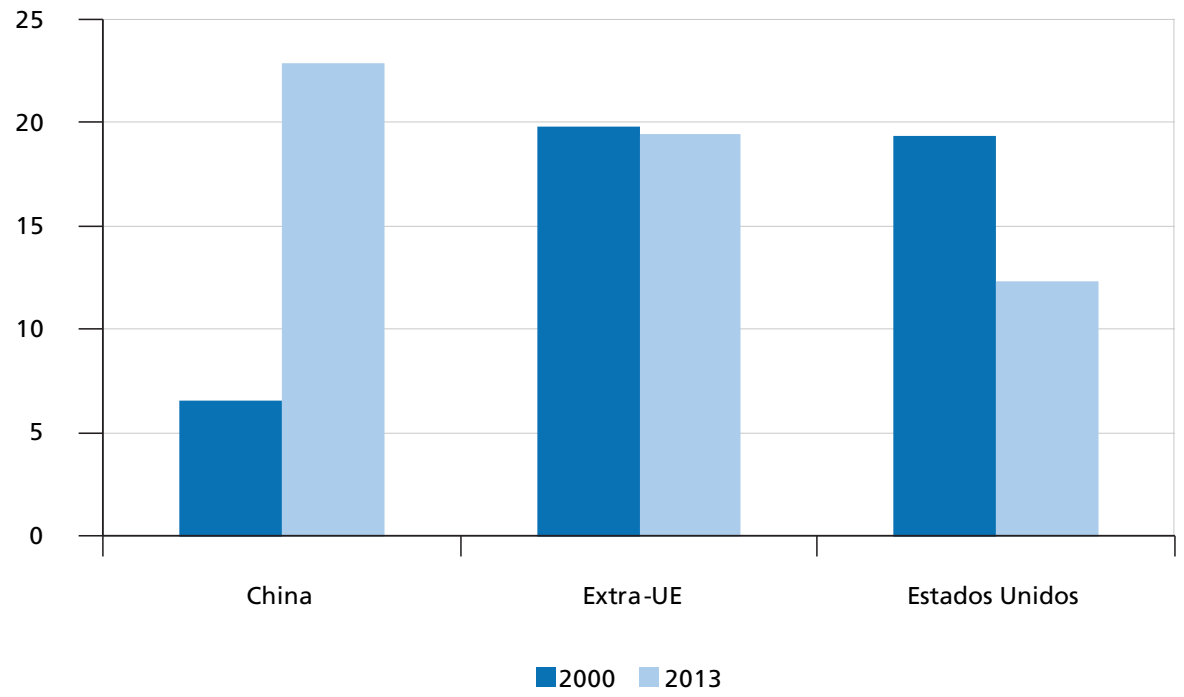

Fonte: OMC, 2014.

Elaboração do autor. 
GRÁFICO 3

China, Estados Unidos e UE: participação nas importações mundiais de bens industriais

(Em \%)

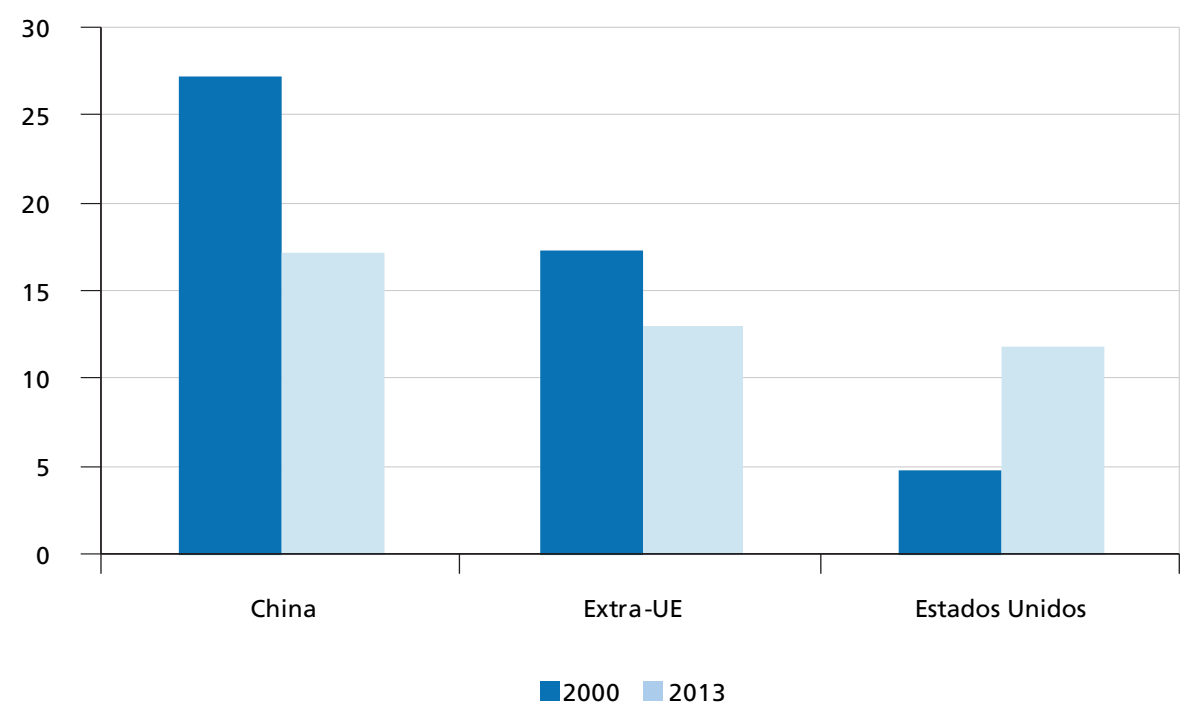

Fonte: OMC, 2014.

Elaboração do autor.

Apesar de ascender na escala de valor, a participação chinesa no comércio de alguns setores mais intensivos em tecnologia parece em grande medida se dever à importância das zonas de processamento de exportaçóes - que representam metade das exportaçóes do país e sáo controladas por empresas transnacionais. Nessas áreas, a participação do valor adicionado industrial no produto industrial bruto mostra-se bastante pequena. Dessa forma, a sua participação como "fábrica global" apenas pode ser compreendida por meio dessa inserção muito particular na divisão internacional do trabalho (GAO, 2012).

Vale lembrar, contudo, que a partir do lançamento do 11을 Plano Quinquenal (2006-2010), a China passou a investir nas suas próprias capacidades tecnológicas, gerando um processo de substituição de importaçóes com diversificação de exportaçóes, contando para tanto com a presença importante das empresas estatais líderes nos setores de média e alta tecnologia. O objetivo era alterar a sua participação ainda subordinada nas cadeias de valor globais lideradas pelas empresas transnacionais, especialmente no setor eletrônico e na indústria de tecnologia da informação (Medeiros, 2013). Uma das formas de enfrentar esse desafio tecnológico e econômico estava na penetração dos mercados externos por meio dos investimentos de suas empresas-líderes, especialmente nos setores de vanguarda (Jacques, 2009). 
Os gráficos a seguir permitem um olhar esquemático sobre os padróes de comércio estabelecidos entre a economia chinesa e os diversos centros e periferias da economia-mundo capitalista.

Observa-se, em primeiro lugar, que, mesmo no comércio bilateral com Estados Unidos e UE, a China é francamente superavitária em bens industriais, com saldos de US\$ 280 bilhóes e US\$ 150 bilhōes, respectivamente, no ano de 2015 (gráficos 4 e 5). O saldo da China com as economias centrais respondia então por $40 \%$ do seu superavit comercial industrial total. No caso dos Estados Unidos, verifica-se inclusive um saldo positivo no comércio de bens primários com a China de US\$ 27 bilhōes - bem maior do que o apurado no caso europeu, cuja agricultura é basicamente voltada para o mercado interno.

\section{GRÁFICO 4}

China-Estados Unidos: saldo comercial por tipo de produto (Em US\$ bilhões)

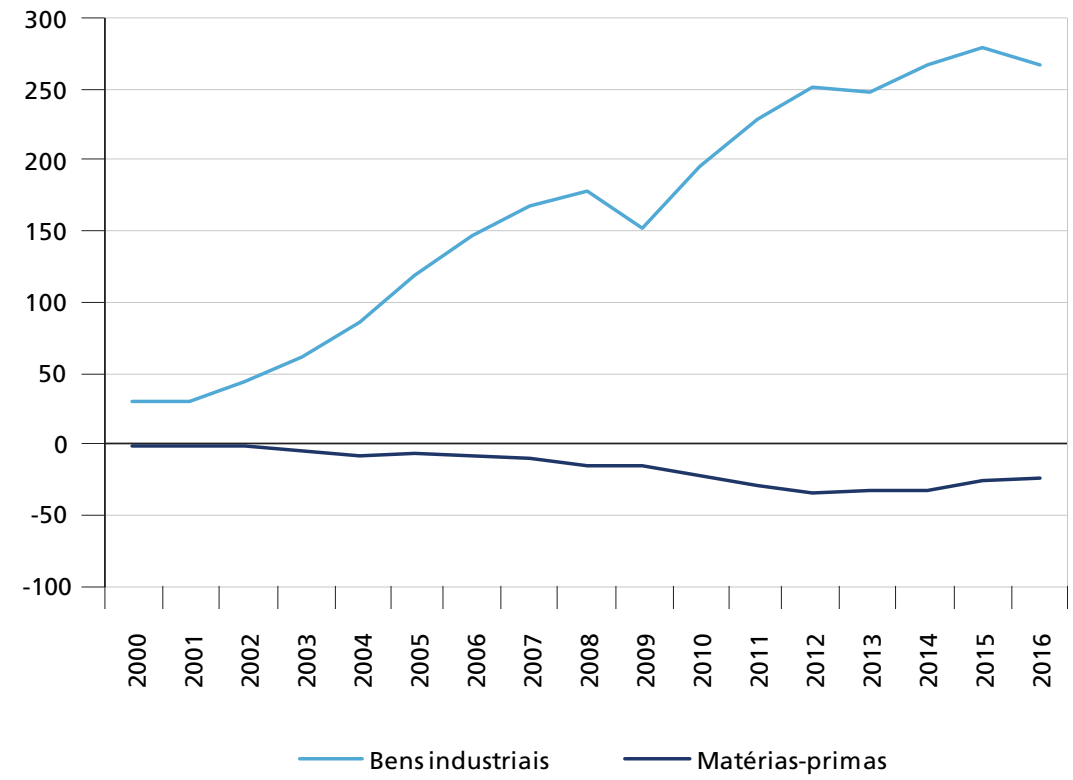

Fonte: UN Comtrade.

Elaboração do autor.

7. Os dados são os reportados pela China ao United Nations Commodity Trade Statistics Database (UN Comtrade). Foram retirados do cálculo das exportações e importações chinesas o comércio com Hong Kong, pois trata-se de um entreposto comercial, distribuindo bens e serviços produzidos na China para o resto do mundo. Por isso, os dados por regiões devem ser vistos com cautela. Entretanto, eles parecem refletir determinados padrões que este texto procura descrever e analisar de maneira sintética. 


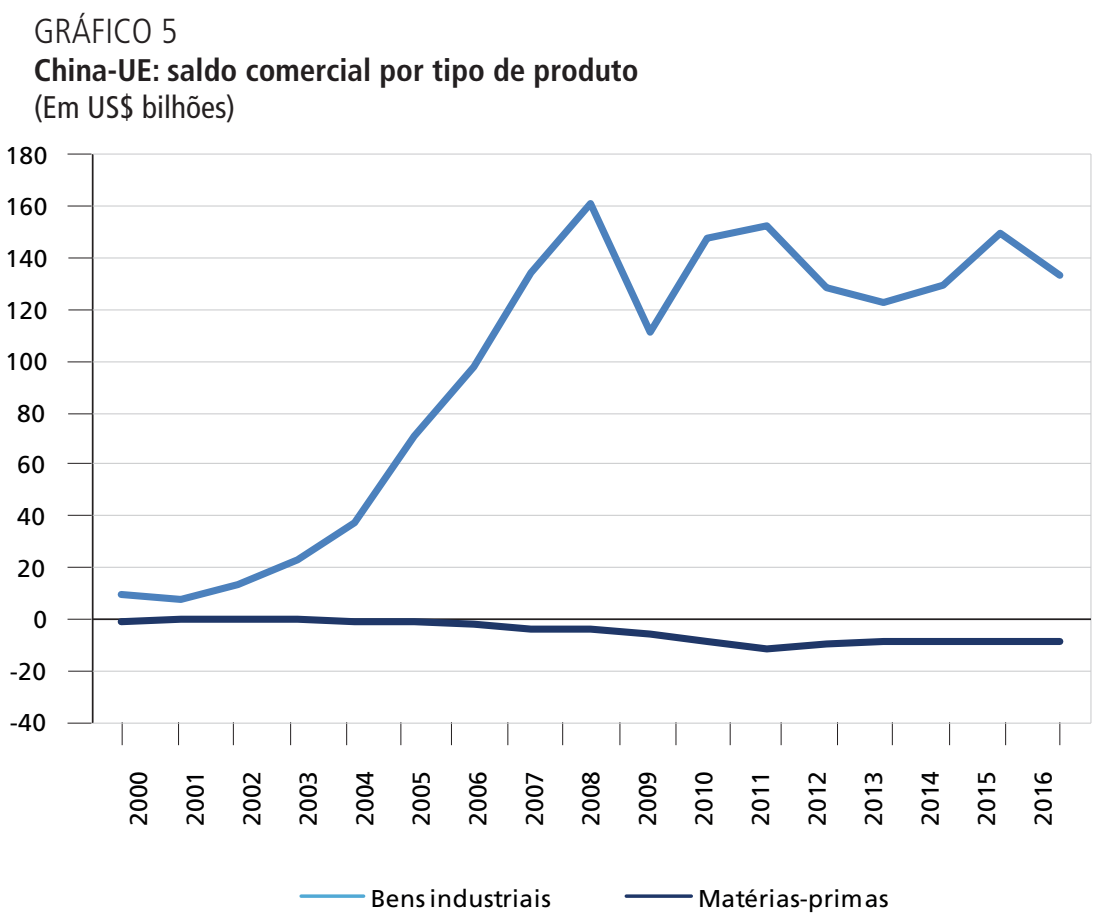

Fonte: UN Comtrade.

Elaboração do autor.

Não obstante, existe um intenso comércio intraindustrial da China com Estados Unidos e UE, que, juntos, respondem por quase um terço das importaçóes industriais chinesas em 2015. O superavit chinês se manifesta em todas as categorias de produto com essas duas regiōes da economia-mundo capitalista, mas se concentra nos bens de consumo. Apesar de superavitária também nos setores de bens de capital, há uma substantiva importação de Estados Unidos e UE, especialmente nos segmentos de fronteira, mas não de maneira disseminada (a Alemanha é a principal origem dessas importações no caso europeu).

Já no caso de Japão e Coreia do Sul, a situação se inverte (gráficos 6 e 7). As estruturas produtivas dessas economias têm se ajustado no sentido de fornecer bens de alto valor agregado para a economia chinesa. Isso se comprova no alto superavit de bens de capital dessas regióes com a China. Apenas no segmento de bens consumo, elas se mostram deficitárias com o gigante asiático. A forte queda do superavit japonês a partir de 2011 provavelmente se deve a problemas das estatísticas chinesas, que devem ser lidas com cautela, mais no sentido de apontar tendências e padróes. Trata-se aqui também fundamentalmente de um comércio intraindustrial. 
A Ascensão Chinesa, as Transformações da Economia-Mundo Capitalista e os Impactos sobre os Padrões de Comércio na América Latina

GRÁFICO 6

China-Japão: saldo comercial por tipo de produto

(Em US\$ bilhões)

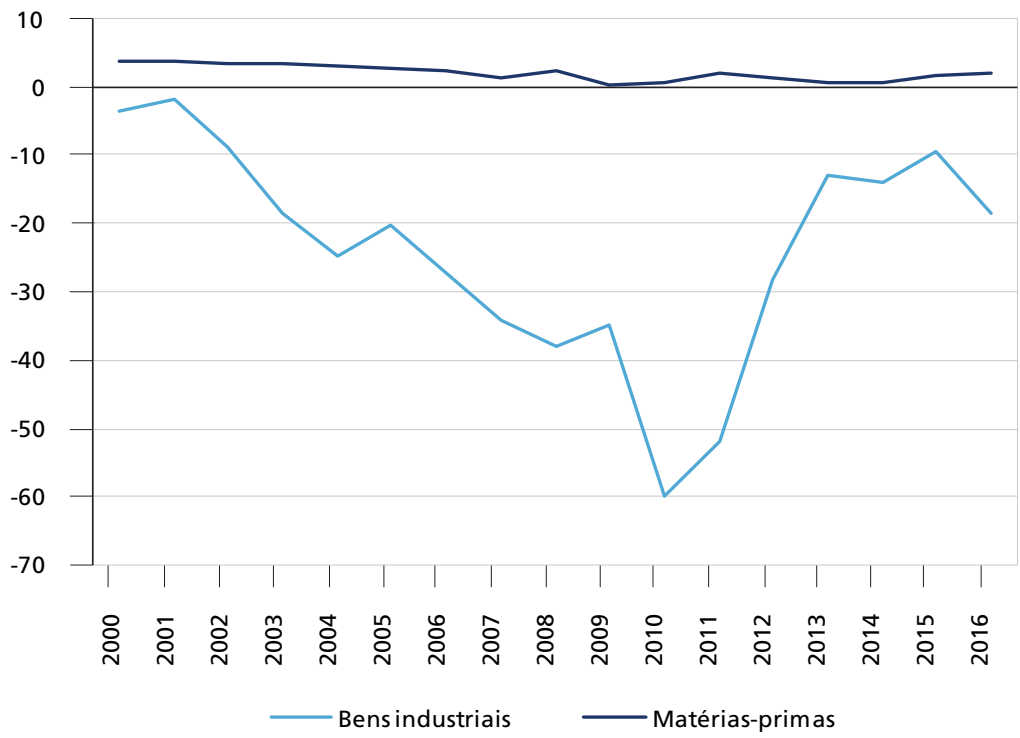

Fonte: UN Comtrade.

Elaboração do autor.

GRÁFICO 7

China-Coreia do Sul: saldo comercial por tipo de produto

(Em US\$ bilhões)

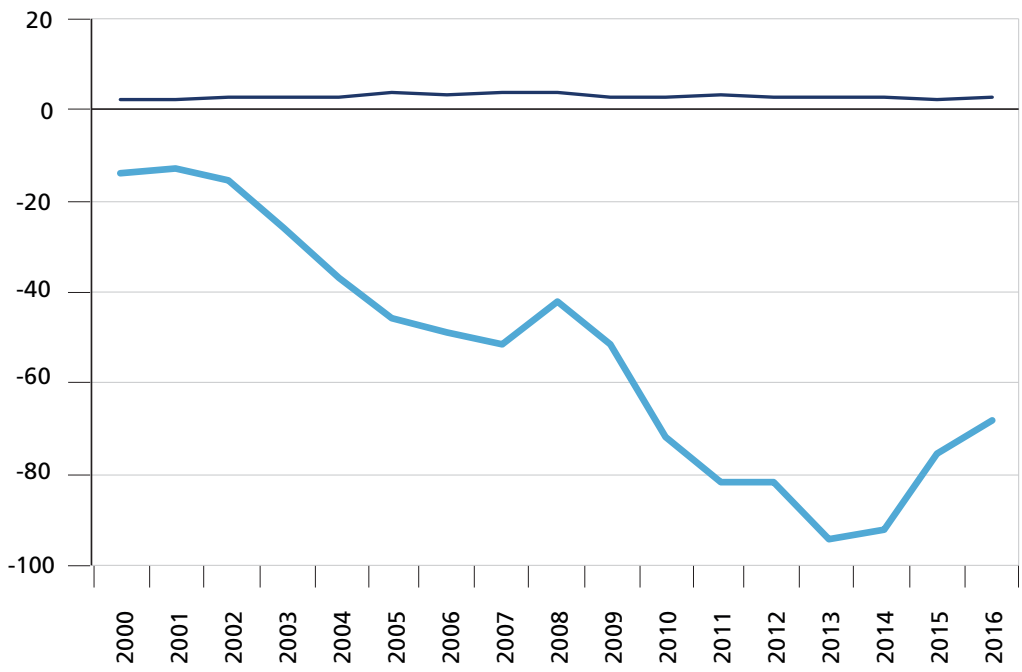

Fonte: UN Comtrade.

Elaboração do autor. 
No caso das economias da América Latina e da África Subsahariana (gráficos 8 e 9), observa-se um padrão de comércio com a China bastante distinto. Essas economias elevaram rapidamente, ao longo dos anos 2000, e mesmo depois da crise, os seus saldos comerciais em matérias-primas. Isso acontece até 2014, pois a partir do ano seguinte teve início uma forte baixa nos preços das commodities minerais e agrícolas. África Subsahariana e América Latina respondem juntas por $29 \%$ do saldo negativo chinês em matérias-primas (12\% e 17\%, respectivamente). Esse percentual atingiu o seu auge em 2008, quando chegou a $34 \%$.

Em ambos os casos, o superavit chinês em bens industriais também saltou de forma exponencial. Na América Latina, o deficit industrial com a China sofreu nova inflexão para cima depois da crise, o que indica que a regiáo serviu especialmente no caso brasileiro, com sua moeda francamente valorizada - como novo mercado a ser aproveitado num contexto de menor crescimento das vendas chinesas para os mercados do Atlântico Norte. Observa-se ainda que a América Latina avançou mais rapidamente como destino de exportaçóes de bens de capital chinês, e a África, como destino de bens de consumo, o que se explica pelas estruturas produtivas das distintas regióes, a primeira demonstrando maior densidade e complexidade na produçáo industrial.

GRÁFICO 8

China-África Subsaariana: saldo comercial por tipo de produto (Em US\$ bilhões)

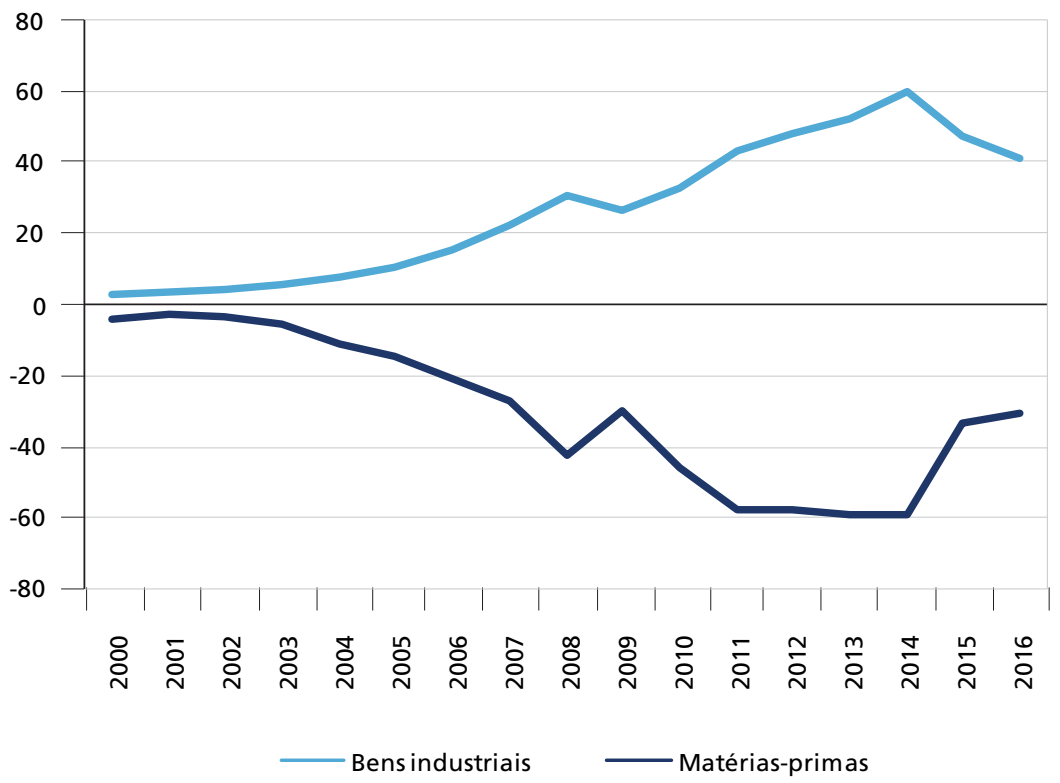

Fonte: UN Comtrade. Elaboração do autor. 


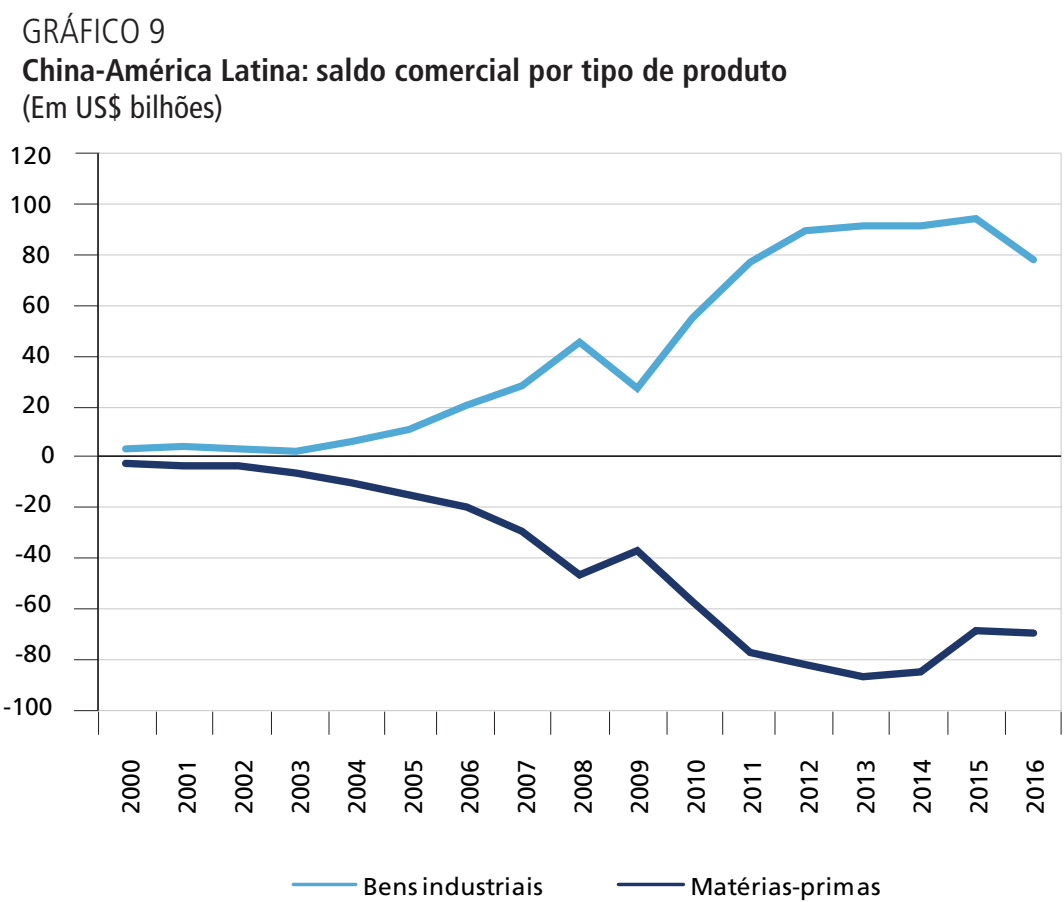

Fonte: UN Comtrade.

Elaboração do autor.

Percebe-se também a presença reduzida de comércio intraindustrial no comércio da China com essas duas regióes da periferia da economia-mundo capitalista. Apesar de sua participação conjunta no total das importaçôes industriais chinesas ter aumentando de $2 \%$ para cerca de 5\% entre 2000 e 2015, América Latina e África Subsaariana são exportadores muito marginais de produtos industriais para a China, sendo mais de três quartos dessas exportaçóes de produtos intermediários de baixo valor adicionado.

No caso do Sudeste Asiático, existem importantes diferenças com relação a América Latina e África Subsaariana. Não somente o superavit de bens primários com a China são menos expressivos como também o deficit de bens industriais mais expressivos. Nesse caso, porém, existe um comércio intraindustrial relativamente volumoso. Em 2015, em termos de percentual de bens industriais importados pelo gigante asiático, a participação dessa região (14\%), em 2015 era três vezes superior à de América Latina e África Subsahariana somadas. Mais importante ainda, os fluxos entre China e Sudeste Asiático revelam-se substantivos em todas as categorias de produtos, o que aponta para a existência de cadeias industriais regionais minimamente integradas. 


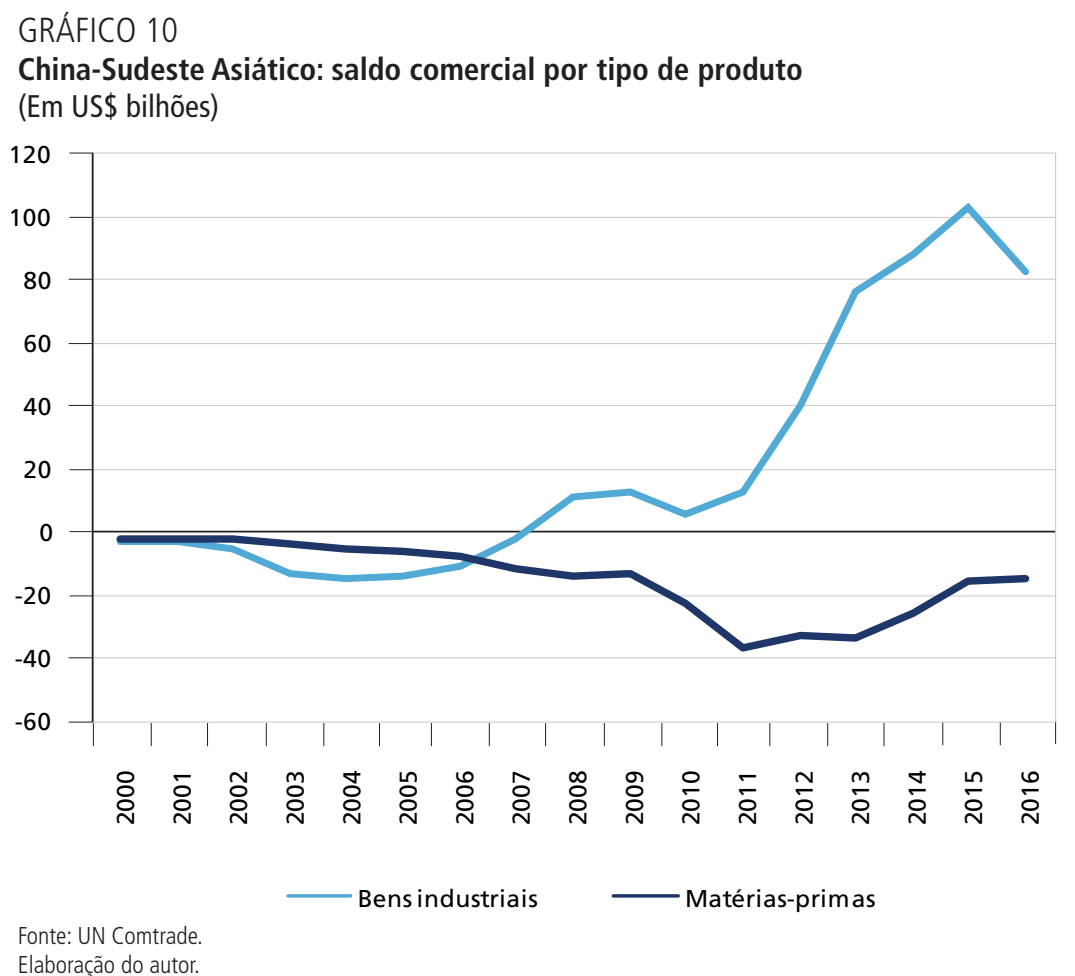

\section{AS RELAÇÕES COMERCIAIS ENTRE CHINA E AMÉRICA LATINA E OS VÁRIOS PADRÕES DE COMÉRCIO REGIONAIS}

Neste tópico buscamos apontar para a existência de vários padróes de comércio da China com a América Latina, em virtude das diferenças de estruturas produtivas e de modelos de inserção externa dos países da região. Começamos apresentando os dados gerais para a soma dos dezenove países que reportaram dados para o UN Comtrade até $2016 .{ }^{8}$

Entre 2000 e 2016, enquanto o comércio exterior da regiáo cresce 2,5 vezes, o comércio com a China multiplica-se por quase vinte vezes (gráfico 11). O crescimento, tanto das exportaçóes como das importaçóes para e da China, encontra-se concentrado em poucos países e produtos. No caso das exportações, cinco países respondem por $70 \%$ das exportações e cinco produtos (todos matérias-primas) respondem por $82 \%$ das vendas externas. Mais de $50 \%$ das importaçôes da região com origem na China são compostas

8. 0 valor total do comércio desses países representa 90\% do comércio total dos 36 países que compreendem a América Latina e o Caribe. Isso acontece porque alguns países não reportaram dados até o final do período. Observa-se ainda que apesar de a tendência ser semelhante à dos dados reportados pela China, nos dados fornecidos pela América Latina o deficit comercial total com o país asiático mostra-se substantivo e crescente. 
de máquinas, equipamentos e componentes industriais (Barbosa, 2011; Barbosa et al. 2015). O deficit comercial da América Latina com a China inclusive se eleva a partir de 2014, em virtude da queda dos preços das commodities e da substituição dos fornecedores tradicionais - Estados Unidos e UE - na região pelas importaçóes chinesas.

\section{GRÁFICO 11}

América Latina-China: balança comercial

(Em US\$ bilhões)

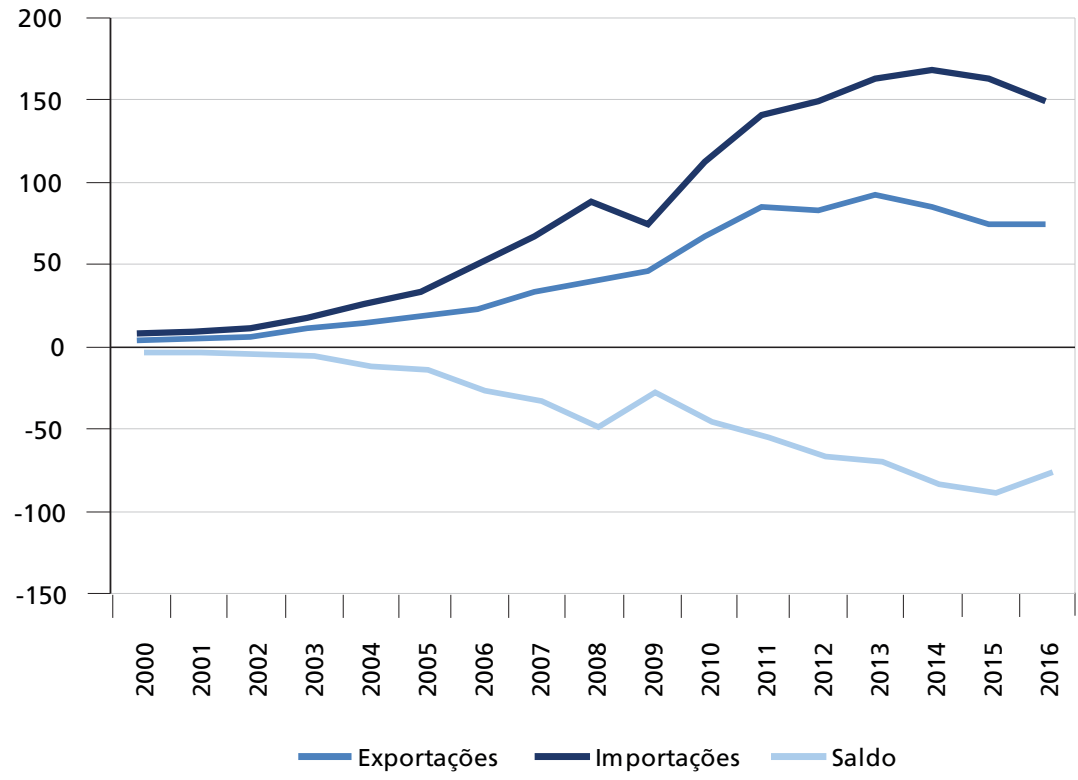

Fonte: UN Comtrade.

Elaboração do autor.

No que se refere às exportaçóes de matérias-primas da América Latina, a China salta entre 2000 e 2016 para o primeiro destino das exportaçóes desses produtos (de 4\% para 25\%), à frente de Estados Unidos e UE (gráfico 12). Já na importaçẫo de bens industriais, se, para a média da região, os Estados Unidos ainda respondiam por 30\% em 2016 (contra mais de 50\% em 2000), a China já respondia no mesmo ano por $20 \%$ (contra um percentual próximo de $0 \% \mathrm{em}$ 2000), seguida da UE, com 15\% (gráfico 13). 
GRÁFICO 12

América Latina: distribuição das exportações de matérias-primas por destino (Em \%)

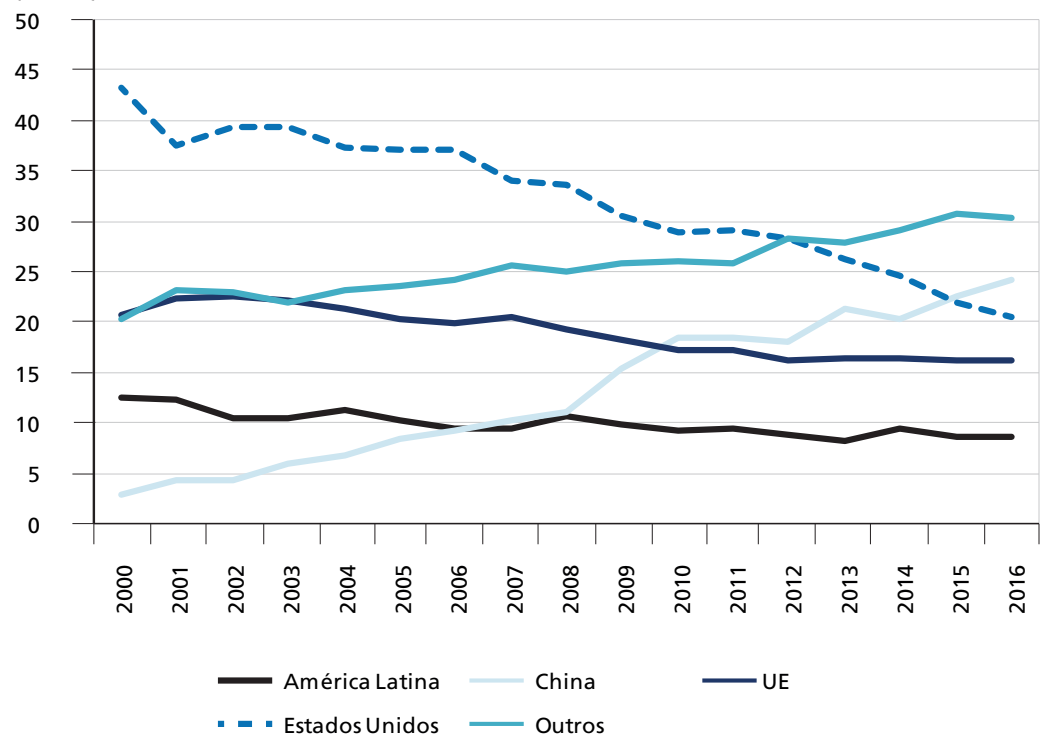

Fonte: UN Comtrade.

Elaboração do autor.

GRÁFICO 13

América Latina: distribuição das importações de bens industriais por origem (Em \%)

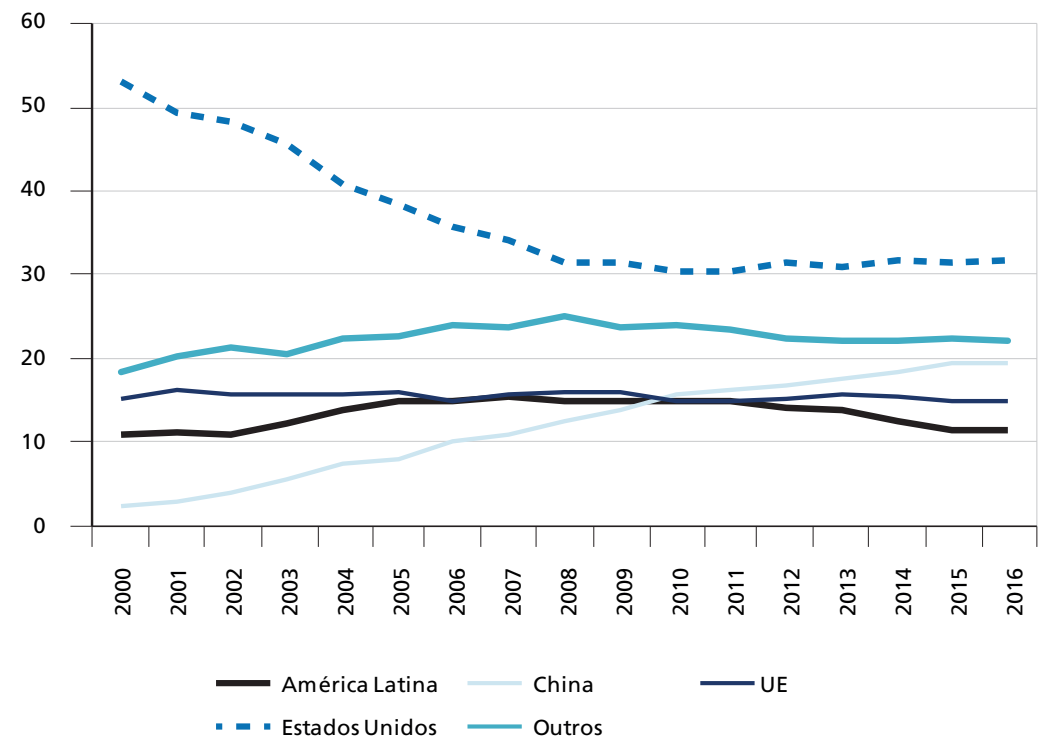

Fonte: UN Comtrade.

Elaboração do autor. 
Quando se analisa o deficit de bens industriais totais da América Latina, a China já respondia por três quartos do saldo negativo em 2016. Isso se deve, em parte, ao saldo positivo com os Estados Unidos (gráfico 14), no contexto de recuperação da economia norte-americana após 2012, em grande medida concentrado no México, o que se explica pelo Acordo de Livre Comércio da América do Norte (North American Free Trade Agreement - NAFTA) e pela presença das maquiladoras mexicanas desse país no comércio com os Estados Unidos.

GRÁFICO 14

América Latina: saldo comercial de bens industriais por regiões

(Em US\$ bilhões)

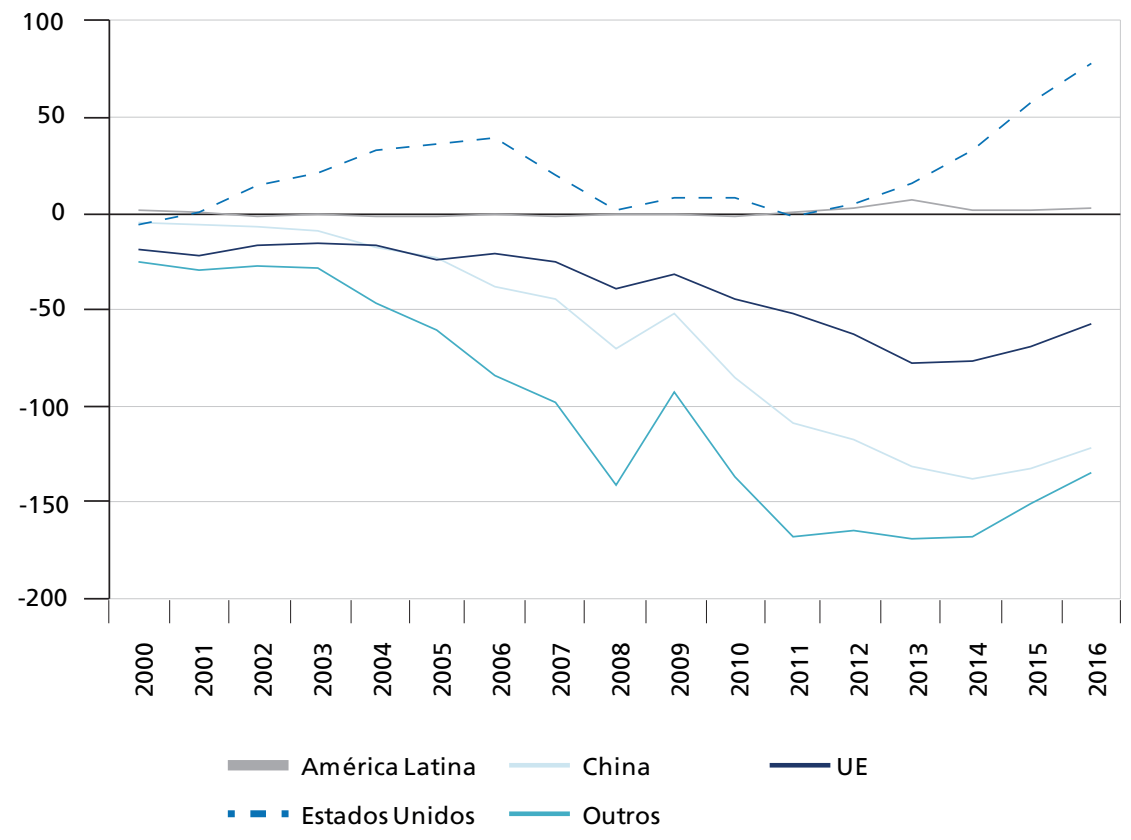

Fonte: UN Comtrade.

Elaboração do autor.

Nesse sentido, podemos lançar a hipótese de que a ascensão chinesa ocasiona uma maior diferenciação nas trajetórias de inserção externa dos países latino-americanos, processo observado já a partir de 1970 por Hirschman (1996). Nesse sentido, a própria noção de uma "economia latino-americana", tal como exposta por Furtado (1986) nos anos 1960, deixa de fazer sentido. A integração regional, que seria um dos alicerces para a reestruturação da inserção na economia internacional, transformando a América Latina numa exportadora de produtos industriais, simplesmente não vingou. 
Isso se deve à fragilidade dos projetos de integraçáo regional, abandonados nos anos 1970, às políticas econômicas executadas pelos países e à crise da dívida externa dos anos 1980. Outros fatores importantes vieram a se somar: a abertura indiscriminada das economias da região nos anos 1990 e a ascensão chinesa que reforçou ou pôs em xeque os diferentes perfis produtivos e de inserção externa dos vários países da América Latina.

Durante os anos 2000, por exemplo, países como Chile e Peru assinaram tratados de livre-comércio com a China. Esses dois países, mais México e Colômbia, também contam com acordos de livre-comércio com os Estados Unidos e com a UE. Esses países encontram-se, portanto, diretamente vinculados a pelo menos dois dos três centros da economia-mundo capitalista. Não à toa decidiram criar, em 2012, a Aliança do Pacífico, que teve pouco significado em termos do comércio intrarregional entre esses países.

Mesmo os países organizados em torno do Mercado Comum do Sul (Mercosul) têm sido afetados pela crescente expansão chinesa, alterando as suas relaçôes comerciais. Isso porque as barreiras tarifárias não têm impedido a China de se firmar como importante exportador para os países que compóem o bloco, deslocando os exportadores das outras regióes centrais, e inclusive do Brasil, que conta com o maior parque industrial da América Latina.

Portanto, as diferenças de padrão de comércio dos países latino-americanos com a China estấo mais relacionadas às estruturas produtivas de cada país do que às suas respectivas estratégias de política comercial e de integração regional, embora essas não deixem de ser relevantes.

Em seguida serão apresentados os casos de México, Brasil, Chile e Bolívia, com base nos dados da CEPAL, no que se refere às relaçôes comerciais desses países com a China e outras regióes econômicas. Esses casos servem como parâmetros ou tipos ideais - para os quatros padrôes de comércio regionais aqui apresentados.

O caso do México é bastante peculiar por sua concentração de exportaçóes em bens industriais para o mercado estadunidense: $85 \%$ das suas vendas externas são industriais, o que dificulta o seu entrosamento com a demanda chinesa, e $80 \%$ das suas exportaçóes se dirigem aos Estados Unidos. Na sequência da crise de 2008, o México expandiu seu superavit de bens industriais com os Estados Unidos e o seu deficit de bens industriais com a China (gráfico 15). Provavelmente, esses movimentos estão interligados. Parte crescente dos que as transnacionais em solo mexicano exportam para os Estados Unidos passou a ser made in China. 


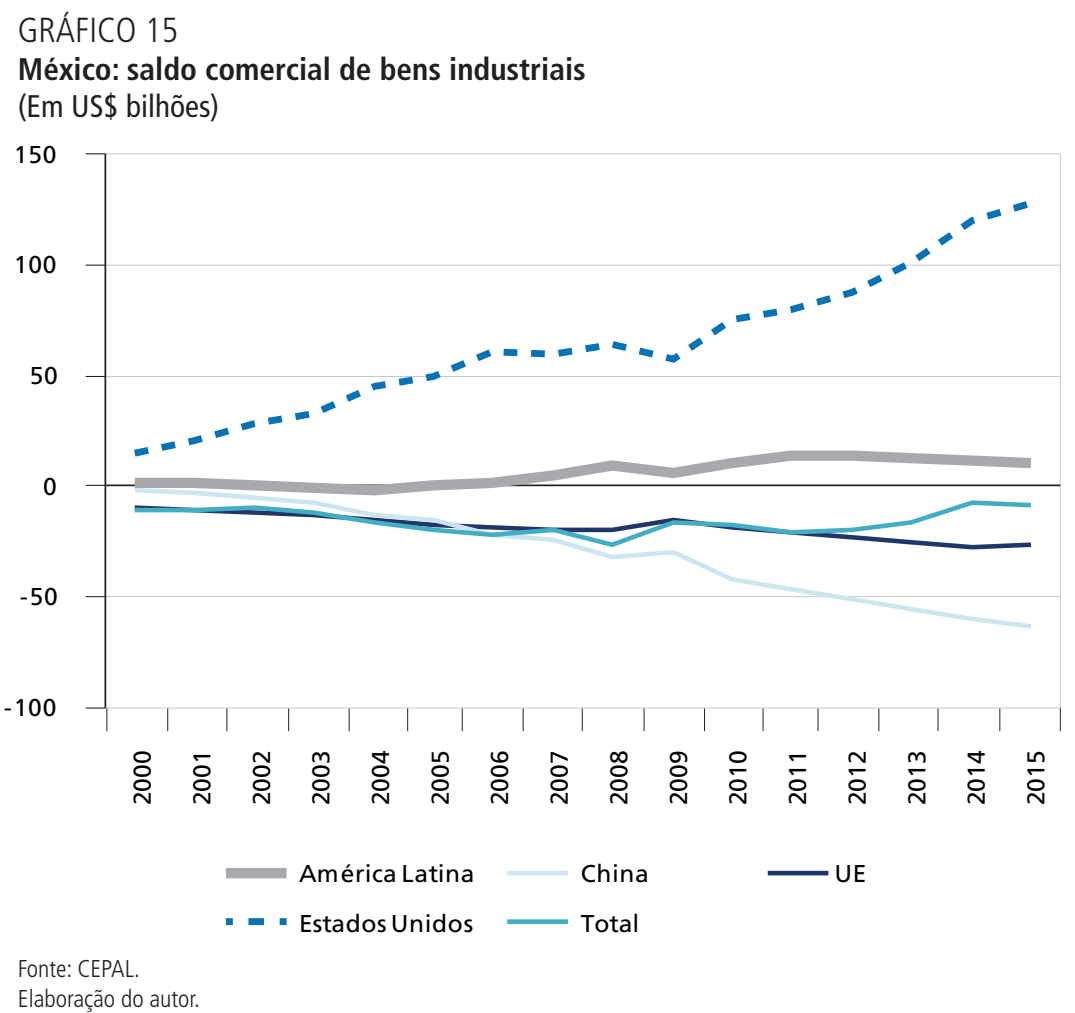

Enquanto os Estados Unidos eram responsáveis por mais de $70 \%$ das importaçóes industriais do México em 2000, esse percentual caiu para 50\% em 2016. Já a China saltou de zero para $20 \%$ nesse período (gráfico 16). O próprio mercado interno mexicano está sendo afetado pela presença chinesa, como também as exportaçóes dos Estados Unidos para o país latino-americano. Por sua vez, a América Latina não tem se firmado como destino importante das exportaçóes mexicanas, o que se comprova pelo pequeno superavit de bens industriais desse país com a região.

O caso brasileiro caracteriza-se pela grande oferta de várias commodities para China (soja, minério de ferro, petróleo, celulose etc.), o que tem levado a superavit crescentes para esse tipo de produto. O pico foi atingido em 2013: saldo comercial de US\$ 40 bilhôes com a China, tendo decrescido para cerca de US\$ 30 bilhóes em 2015 (gráfico 17). Não obstante, o Brasil segue como importante exportador industrial, com 40\% das exportaçóes destinadas à América Latina e outros 40\% para Estados Unidos e UE somados (gráfico 18). Paralelamente, 43\% do deficit comercial brasileiro com bens industriais já é originário da relação com a China (gráfico 19), afetando tanto a produção interna como o potencial de exportação para os demais países latino-americanos, onde a presença chinesa é crescente. 
GRÁFICO 16

México: origem das importações industriais por regiões

(Em \%)

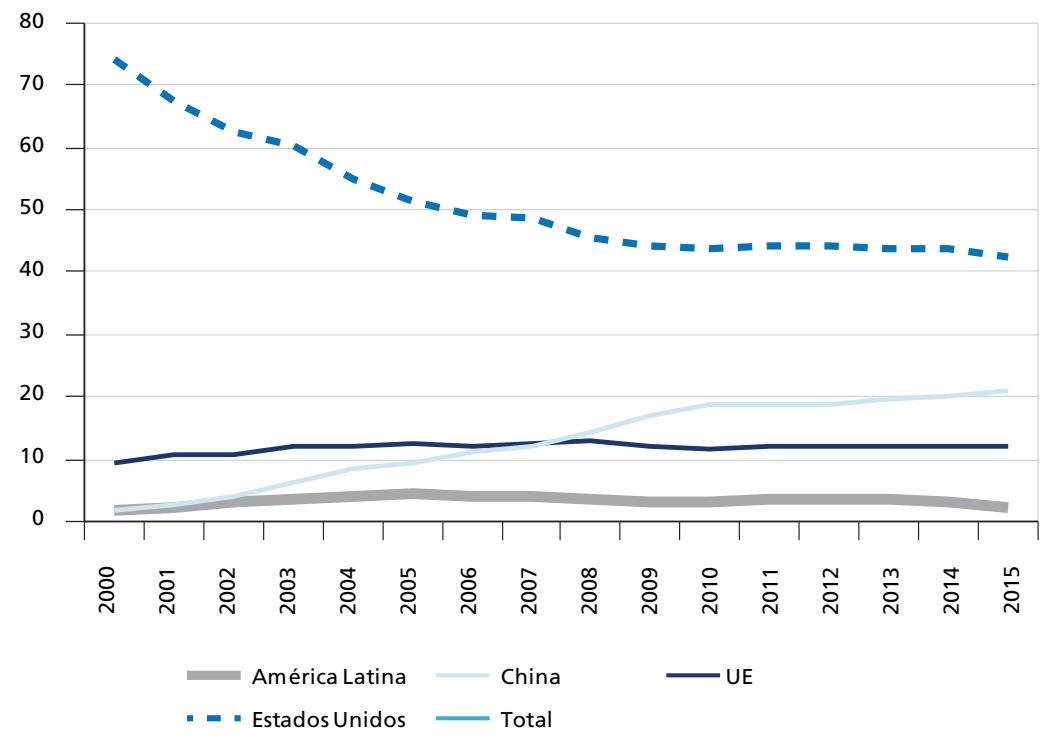

Fonte: CEPAL.

Elaboração do autor.

GRÁFICO 17

Brasil: saldo comercial de matérias-primas

(Em US\$ bilhões)

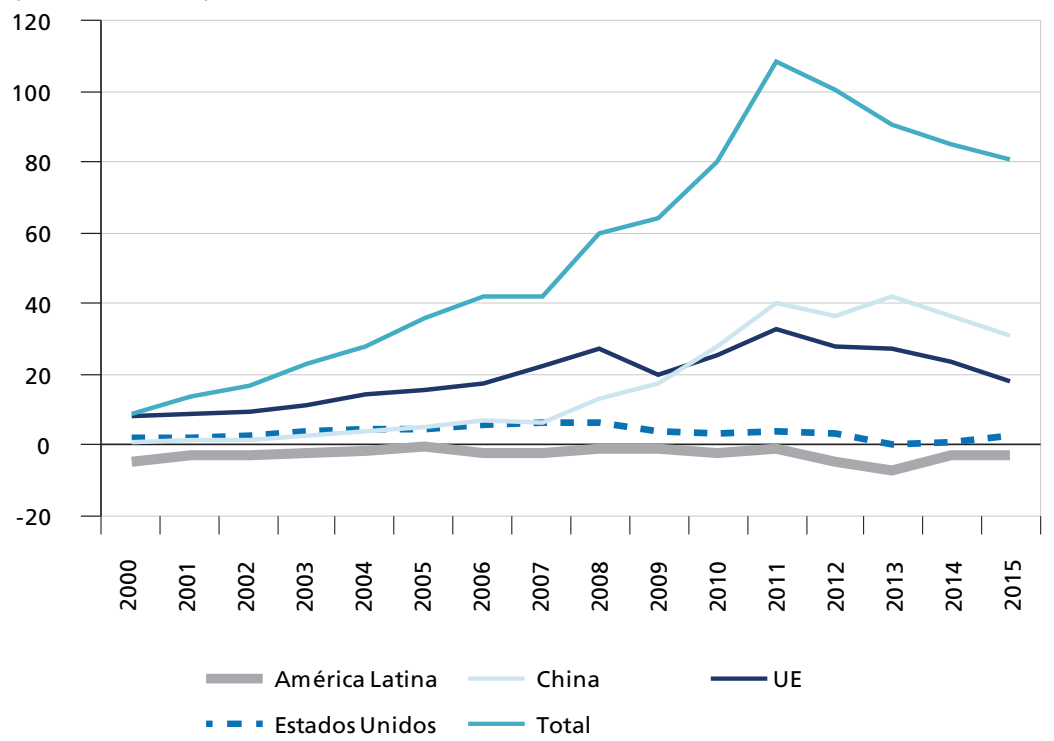

Fonte: CEPAL.

Elaboração do autor. 
A Ascensão Chinesa, as Transformações da Economia-Mundo Capitalista e os Impactos sobre os Padrões de Comércio na América Latina

GRÁFICO 18

Brasil: destino das exportações industriais por regiões

(Em \%)

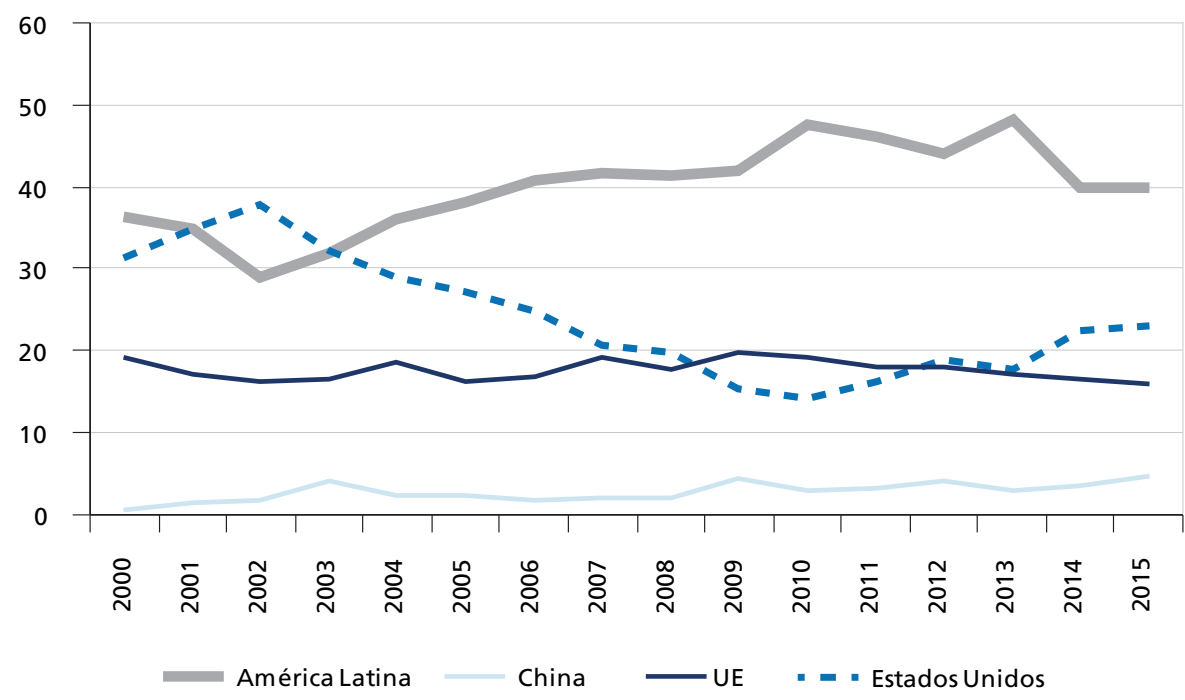

Fonte: CEPAL.

Elaboração do autor.

GRÁFICO 19

Brasil: saldo comercial de bens industriais (em milhões de USD) (Em US\$ bilhões)

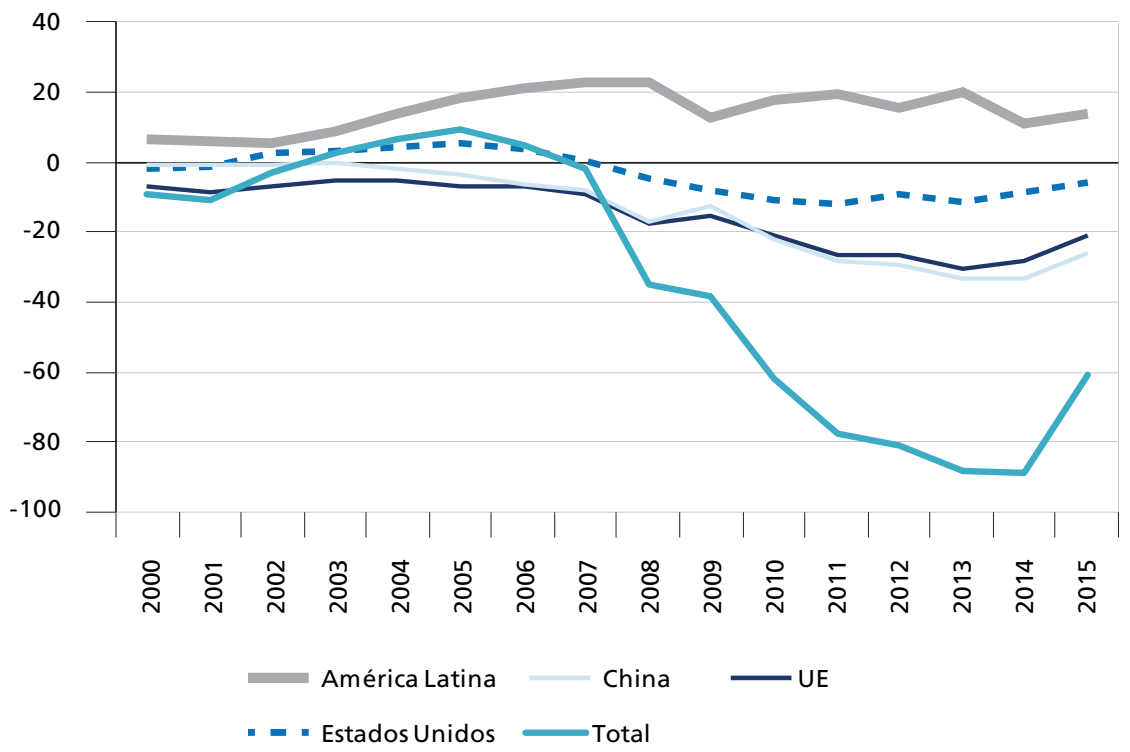

Fonte: CEPAL.

Elaboração do autor. 
O caso argentino mostra-se semelhante ao brasileiro no sentido de que o país é altamente superavitário em commodities e deficitário em bens industriais, com crescente presença chinesa no saldo negativo. A indústria argentina, no entanto, é bem mais dependente do comércio regional, haja vista que $73 \%$ das exportaçôes industriais do país se destinam à América Latina, com destaque para o mercado brasileiro.

Essas duas situaçôes - México e Brasil - não encontram paralelo nos demais países latino-americanos, que tendem a replicar o padrấo chileno ou boliviano, como veremos em seguida.

O Chile destaca-se por apresentar a maior participação da China no total das exportaçôes (26,3\% em 2015) (gráfico 20), entre os países latino-americanos, o que se deve, em grande medida, às exportaçóes de cobre. Trata-se de uma especialização numa matéria-prima largamente demandada pela China e que conta com capacidade de oferta pelo país.

GRÁFICO 20

Chile: destino das exportações por regiões (Em \%)

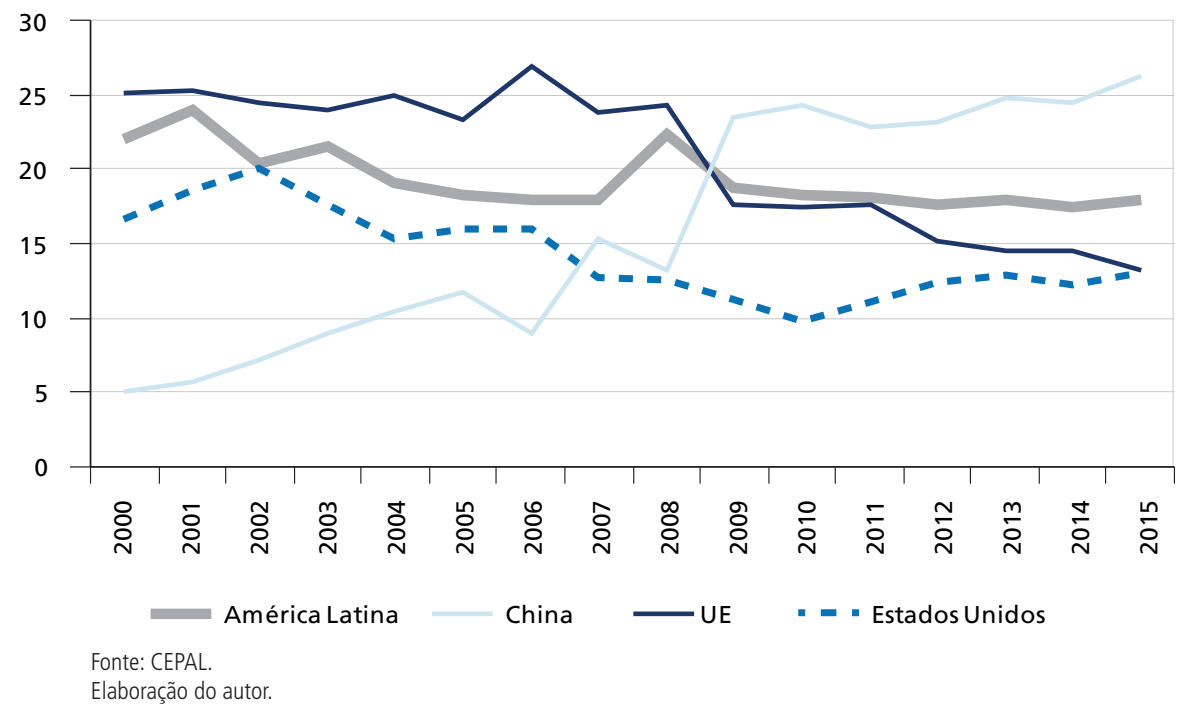

Ao observarmos as exportaçóes industriais chilenas - que representam 14\% do total exportado pelo país - verificamos, entretanto, que a América Latina é o maior mercado, 60\% do total, seguida de longe pelos Estados Unidos (18,4\%), UE (9,1\%) e China (2,7\%) (gráfico 21). Portanto, a assinatura de tratados de livre-comércio (TLCs) com os países do Norte não ampliou o potencial exportador da China, ao menos nos bens industriais. Paralelamente, o país asiático já responde por 30\% das importaçôes industriais do Chile, contra 34\% de Estados Unidos e UE somados (gráfico 22). 


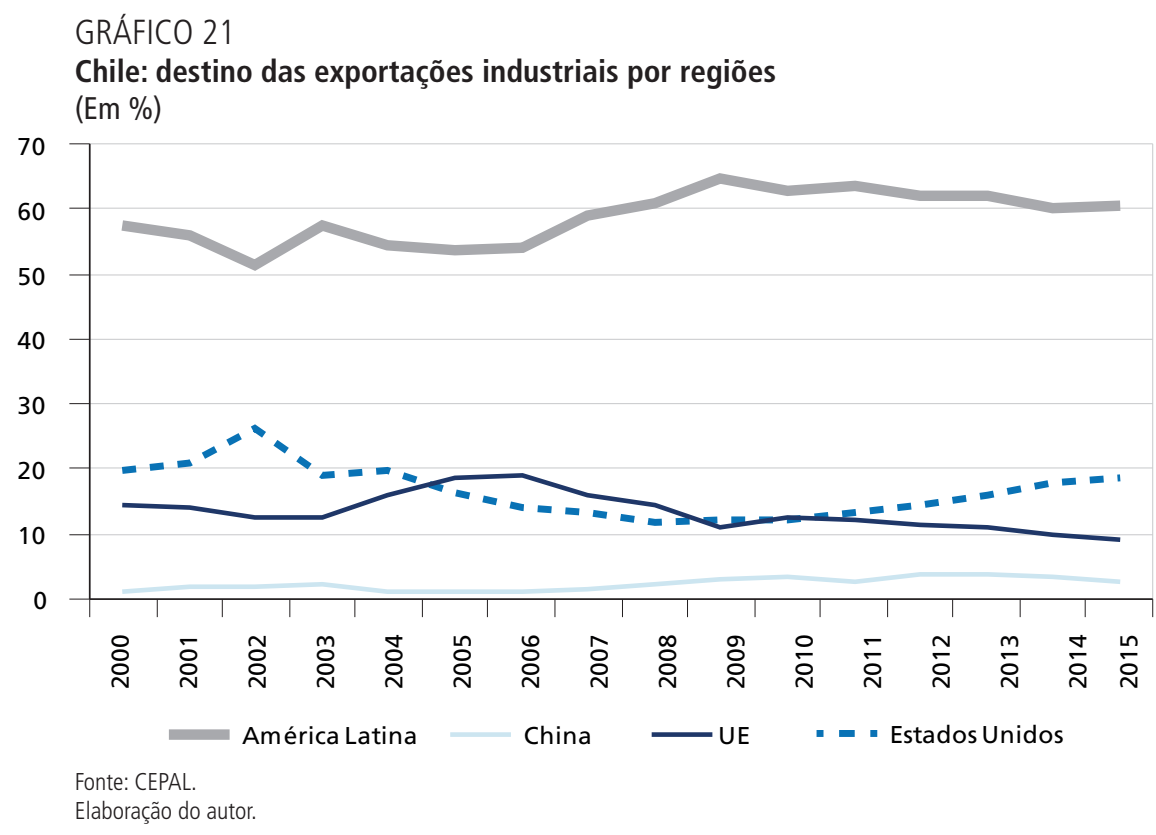

GRÁFICO 22

Chile: origem das importações industriais por regiões (Em \%)

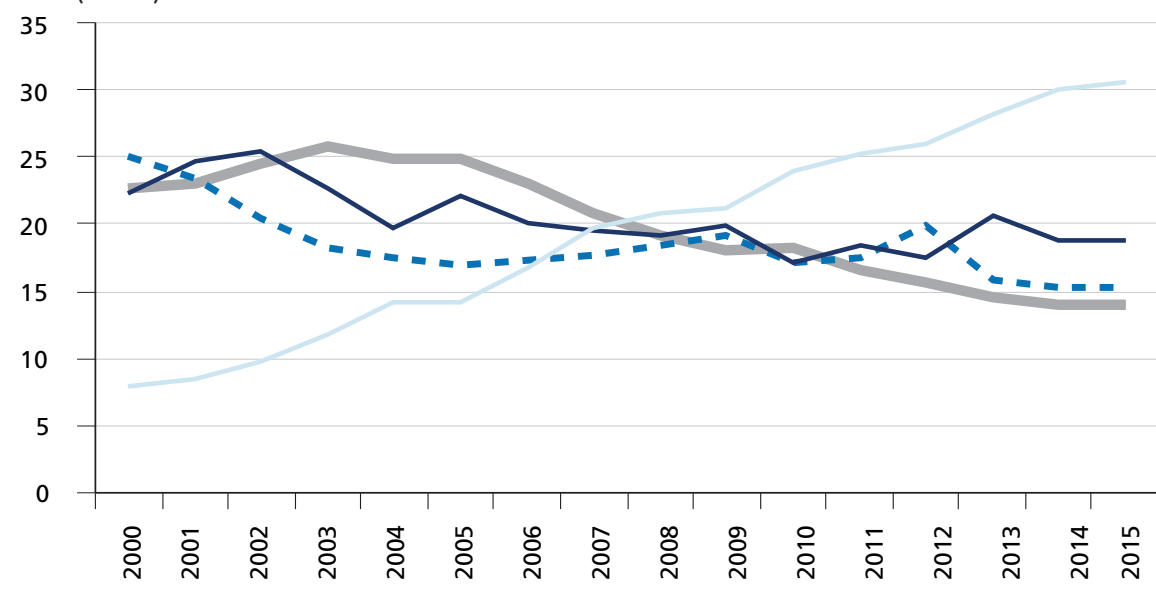

América Latina China UE - Estados Unidos

Fonte: CEPAL.

Elaboração do autor.

O Peru é o país que mais se assemelha com o Chile. Grande exportador de minério de ferro para China, que já ocupa a dianteira como destino de suas exportaçóes $(22,1 \%$ em 2015). A China também é a origem de $29 \%$ das 
importaçôes industriais do país, percentual idêntico ao de Estados Unidos e UE somados. Tal como no Chile, as exportações peruanas de bens industriais (12,3\% do total) se dirigem preferencialmente ao mercado regional. A única diferença expressiva é que o saldo positivo em bens primários do Chile com a China consegue preencher o saldo negativo em bens industriais, o que náo acontece no Peru.

O caso boliviano, cuja pauta de exportaçóes se concentra em bens primários ( $94 \%$ do total), se caracteriza pelo potencial ainda náo aproveitado do mercado chinês. A Bolívia exporta para a China minérios, metais e combustíveis, mas o percentual exportado para o país asiático ainda se mostra reduzido, $5,2 \%$ do total em 2015 (contra 0,4\% em 2001) (gráfico 23), ficando nesse quesito a China ainda atrás de Estados Unidos e UE. A América Latina responde por quase $60 \%$ das exportaçóes bolivianas. Por sua vez, a China já aparece com um percentual de $20 \%$ do total de bens industriais importados pela Bolívia, bem à frente de Estados Unidos e UE, e atrás apenas da América Latina (gráfico 24).

GRÁFICO 23

Bolívia: destino das exportações por regiões

(Em \%)

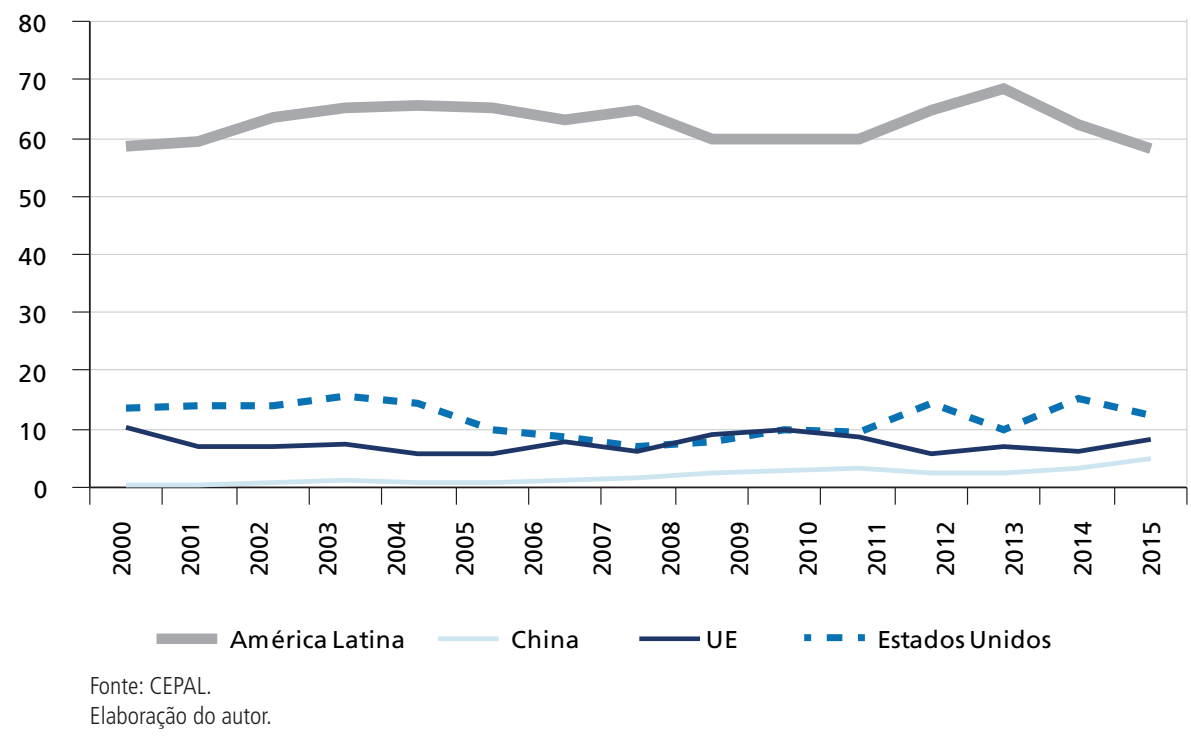

A Bolívia aparece como caso típico de país pequeno e exportador de produtos primários da América Latina que ainda náo aproveitou o potencial de exportaçôes, inclusive do setor agrícola, para o mercado chinês. Esse também parece ser o caso do Uruguai, por exemplo, que em 2014 já possuía $17 \%$ das suas exportaçóes voltadas para o mercado chinês - basicamente soja, carnes, lã e couro - acima dos percentuais de Estados Unidos e UE. Já as importaçôes de bens 
industriais da China representam 26\% do total, perdendo apenas para a América Latina - especialmente o Mercosul -, com 32\%.

GRÁFICO 24

Bolívia: origem das importações industriais por regiões (Em \%)

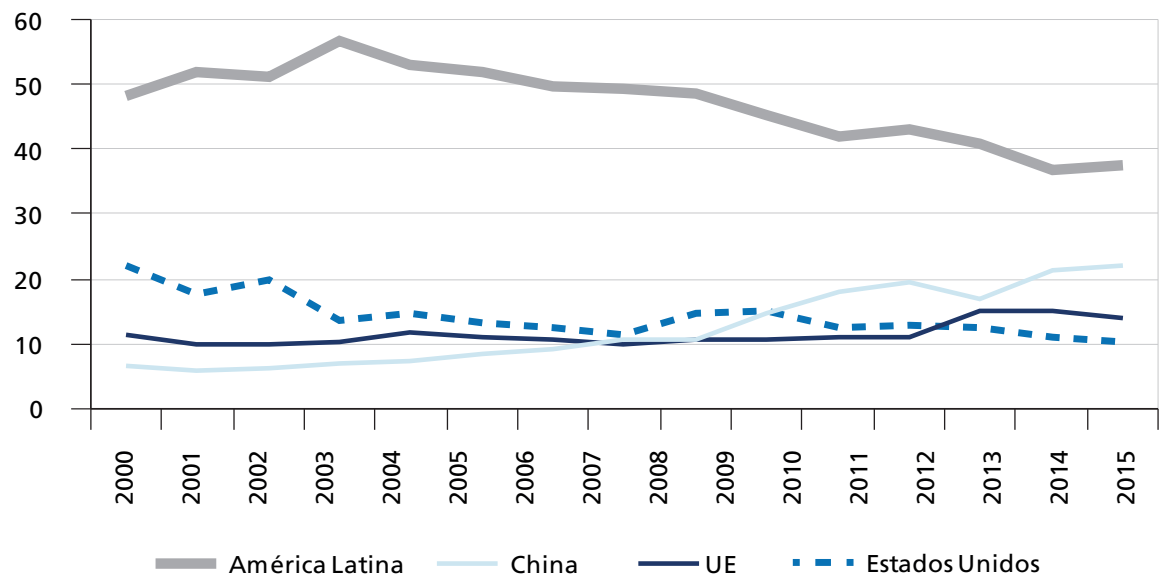

Fonte: CEPAL.

Elaboração do autor.

Os quatro padróes de comércio com a China aqui apresentados podem ser resumidos de maneira sintética.

O primeiro caso é representado pelo México: ausência de oferta de matérias-primas e penetração de bens industriais chineses no mercado interno e como insumos, componentes e máquinas para as maquiladoras mexicanas ainda voltadas para o mercado dos Estados Unidos.

O Brasil conforma o segundo caso, também não passível de replicação, talvez em menor medida pela Argentina: reforço da exportação de commodities com maior especialização da estrutura produtiva, elevação do componente importado da China, além de deslocamento das suas exportaçóes industriais para a América Latina.

Esses dois casos de padrão comercial trazem questionamentos para as opçóes de inserção externa das duas grandes economias na América Latina. A ascensão chinesa coloca em xeque a opção "maquila" para o México e a opção do mercado interno como âncora para a uma plataforma de exportação industrial para a região no caso brasileiro.

O terceiro caso conformado por Chile e Peru significa o aproveitamento de uma especialização beneficiada pela ascensão chinesa, o que pode levar os 
níveis de crescimento econômico acima da média latino-americana. $\mathrm{O}$ padrão de comércio existente, porém, impede uma maior diversificação produtiva, assim como obstaculiza qualquer tentativa mais robusta de enfrentamento da desigualdade.

O quarto caso é o que parece estar emergindo na Bolívia, e que se observa também no Uruguai. A China amplia a oferta exportadora, mas também bloqueia a possibilidade de agregaçấo de valor internamente. Os resultados econômicos positivos no curto prazo, tal como no caso de Chile e Peru, podem ser contraproducentes no longo prazo.

\section{CONSIDERAÇÕES FINAIS}

Este artigo procurou mostrar as limitaçóes dos conceitos fundados no "discurso da globalização" tanto para a compreensão dos novos desafios enfrentados pelos países da América Latina como para a formulação de políticas para o desenvolvimento.

Partindo de uma reflexão conceitual em torno de autores sistêmicos como Braudel, Wallerstein Arrighi e Harvey; de autores preocupados com a nova dinâmica espacial do capitalismo, como Dicken, Castells e Sassen; e dos autores clássicos da CEPAL, como Prebisch e Furtado; lançamos algumas hipóteses sobre a nova configuração da economia-mundo capitalista no contexto da ascensão chinesa.

Tal fenômeno não pode ser compreendido como se trouxesse mudanças apenas quantitativas. A própria dinâmica do capitalismo se vê alterada por meio do funcionamento de três centros dinâmicos atuando de forma complementar e crescentemente contraditória, em especial depois da crise de 2008, e interagindo de maneira diferenciada com as regióes periféricas. Trata-se de uma des(re) organização estrutural com relação ao contexto histórico em vigor até 1980.

As relaçóes comerciais da China com as várias regiôes centrais e periféricas da economia-mundo capitalista são mapeadas em termos empíricos, com o objetivo de apurar a especificidade latino-americana. A fragmentação dessa regiáo em termos econômicos fica patente, por meio da conformação de pelos menos quadro padróes de comércio exemplificados por México, Brasil, Chile e Bolívia.

Observa-se que a crescente presença chinesa reforça essa fragmentação regional, a despeito das diferentes estratégias de inserção externa e políticas de comércio exterior acionadas pelos países latino-americanos. A própria divisão entre países desenvolvidos e subdesenvolvidos deixa de fazer sentido, já que as várias regióes/países possuem padróes específicos de integração na economia-mundo capitalista.

O texto demonstra, por fim, que a adoção de novas políticas e estratégias de desenvolvimento e de integração regional na América Latina exige um esforço 
prévio de reformulação teórica. A industrialização, com reformas internas e externas, não mais conduz ao "desenvolvimento".

Nenhum projeto de desenvolvimento, entretanto, parece possível sem a recuperação da indústria, da capacidade interna de agregação de valor, do potencial tecnológico desperdiçado nas últimas décadas e de uma avaliação crítica sobre o desgaste dos recursos não renováveis. Mais ainda, os elos intersetoriais precisam ser reforçados. Para tanto, requer-se o aproveitamento das complementaridades existentes entre países da região e o estímulo à geração de novas capacidades, estruturas e centros de decisão. Isso não se faz sem a coordenação dos Estados Nacionais, procurando atuar também sobre as eventuais brechas oriundas das disputas entre os três centros hegemônicos, inclusive no sentido de resgatar uma nova perspectiva regionalista.

Se a pandemia do novo coronavírus tende a gerar impactos consideráveis sobre o funcionamento da economia-mundo capitalista e, consequentemente, sobre as economias e sociedades latino-americanas, os dilemas estruturais a serem enfrentados residem em grande medida nos padrôes de inserção externa e nos seus impactos sobre o potencial de desenvolvimento dos diferentes países da região. Afinal, nenhuma mudança, por maior que seja o seu alcance e escopo, traz uma ruptura completa com o passado.

\section{REFERÊNCIAS}

ARRIGHI, G. O longo século XX. Rio de Janeiro: Contraponto, 1996.

. A ilusão do desenvolvimento. Petrópolis: Vozes, 1997.

Adam smith in Beijing: lineages of the twenty-first century. London: Verso, 2007.

BARBOSA, A. F. China e América Latina na nova divisão internacional do trabalho. In: A China nova configuraçáo global: impactos políticos e econômicos, LEÃO, R.; COSTA PINTO; E. ACIOLY, L. (Orgs.). Brasília: Ipea, 2011. p. 270-305.

BARBOSA, A. F. et al. Presença chinesa na África e na América Latina. In: IPEA INSTITUTO DE PESQUISA ECONÔMICA APLICADA. (Org.). Relatório de pesquisa para o Ministério da Fazenda. Brasília: Ipea, 2015.

BRAUDEL, F. La dynamique du capitalisme. Paris: Flammarion, 1985.

Civilizaçáo material, economia e capitalismo: séculos XV-XVIII Os jogos das trocas. Sáo Paulo: Martins Fontes, 1996a. v. 2.

Civilizaçáo material, economia e capitalismo: séculos XV-XVIII -

O tempo do mundo. São Paulo: Martins Fontes, 1996b. v. 3. 
BRAUTIGAM, D. The dragon's gift: the real story of China in Africa. New York: Oxford University Press, 2009.

CASTELLS, M. A era da informaçáo: economia, sociedade e cultura - a sociedade em rede, 3. ed. v. 1. São Paulo: Paz e Terra, 2000.

CASTRO, A. B. From semi-estagnation to growth in a sino-centric market. Revista de Economia Política, São Paulo, v. 28, n. 1, 2008.

CHESNAIS, F. O capital portador de juros: acumulação, internacionalização, efeitos econômicos e políticos. In: A Finança mundializada, CHESNAIS, F. (Org.). São Paulo, Boitempo Editorial, 2005.

Finance capital today: corporations and banks in the lasting global slump. Leiden, Brill. 2016.

DICKEN, P. Global shift: transforming the world economy. New York: The Guilford Press, 1998.

EVANS, P. Dependent Development: the alliance of multinational, State and local capital in Brazil. Princeton: Princeton University Press, 1979.

FRIEDMAN, T. The world is flat: a brief history of the twenty-first century. New York: Farrar, Straus and Giroux, 2006.

FURTADO, C. O mito do desenvolvimento econômico. Rio de Janeiro: Paz e Terra, 1974.

A economia latino-americana. 3. ed. São Paulo: Companhia Editora Nacional, 1986.

Introduçáo ao desenvolvimento: enfoque histórico-estrutural. 3. ed. São Paulo, Paz e Terra, 2000.

GAO, Y. China as the workshop of the world - an analysis at the national and industrial level of China in the international division of labor. New York: Routeledge, 2012.

HARVEY, D. A produçáo capitalista do espaço. 2. ed. São Paulo: Annablume, 2006.

HIRSCHMAN, A. Auto-subversão: teorias consagradas em xeque. São Paulo, Companhia das Letras, 1996.

HOBSBAWM, E. O novo século - entrevista a Antonio Polito). São Paulo: Companhia das Letras, 2000.

JACQUES, M. When China rules the world: the end of the western world and the birth of a new global order. New York: The Penguin Press, 2009 
KOSELLECK, R. Futuro passado: contribuição à semântica dos tempos históricos. Rio de Janeiro: Contraponto, 2011.

MEDEIROS, C. A. Padróes de investimento, mudança institucional e transformação estrutural na economia chinesa. In: Padróes de desenvolvimento econômico (1950-2008): América Latina, Ásia e Rússia, BIELSCHOWSKY, R. (Org.). Brasília: CGEE, 2013, p. 435-489.

OECD - ORGANISATION FOR ECONOMIC COOPERATION AND DEVELOPMENT. Chinese export credits policies and programmes. Paris: OECD, mar. 2015.

PREBISCH, R. Capitalismo periférico: crisis y transformación. México: Fondo de Cultura Económica, 1981.

SASSEN, S. Los espectros de la globalización. Buenos Aires: Fondo de Cultura Económica, 2003.

Expulsóes: brutalidade e complexidade na economia global. Rio de Janeiro: Paz e Terra, 2016.

SCISSORS, D. China's investment in the world increasing, not soaring. Washington: American Enterprise Institute, 2015.

SHAMBAUGH, D. China goes global: the partial power. Oxford: Oxford University Press, 2013.

STIGLITZ, J. Freefall: free markets and the sinking of the global economy. London: Penguin, 2010.

WALLERSTEIN, I. The capitalist world-economy. Cambridge: Cambridge University Press, 1979.

. Historical capitalism with capitalist civilization. London: Verso, 1995. 
